\title{
Top Indian wealth shares and inheritances 1966-1985
}

\author{
Rishabh Kumar
}

This version: Sept 2019

\begin{abstract}
Between 1953 and 1985 India implemented various progressive taxes on personal wealth. I use estate tax returns to compute top wealth shares (top $1 \%$, top $0.1 \%$ and top $0.01 \%$ ) over 1966 1985; a period marked explicitly by a dirigiste policy environment. These new series suggest that wealth concentration in India reduced substantially during the 1970s. Although the decline affected the entire top $1 \%$, the losses faced by the top $0.01 \%$ were especially large. Combined with identical trends in top income shares, it appears that the 1950-1980 expropriations of India's rich had similarities to institutional transitions and shocks faced by European elites in the early to mid twentieth century.
\end{abstract}

Keywords India Inheritance $\cdot$ Wealth inequality - Top wealth shares · Estate multiplier

JEL Codes: D31, N35

R. Kumar

Department of Economics

California State University, San Bernardino

E-mail: rishabh.kumar@csusb.edu 


\section{Introduction}

This article makes an original contribution to the literature on wealth concentration: it provides new annual series on top wealth shares in India between 1966-1985 using estate tax tabulations. The key finding is that over this period, India's rich faced a dramatic wealth leveling; the share of personal wealth held by the top $1 \%$ reduced from around $16 \%$ in 1966 to approximately $6 \%-7 \%$ by 1985 . These results support the findings of Banerjee and Piketty (2005), who show that the 1960s and 1970s had the largest reductions in Indian income concentration during the twentieth century.

The political economy of the 1950-1980 period is of special interest as a context to these wealth series. British colonial rule ended in 1947, and newly independent India entered into a dirigiste, inward-oriented economic regime that lasted for the next three decades. Real national income grew at $3.5 \%$ on an annual basis. This relatively low growth rate ${ }^{1}$ came to be known as the "Hindu" rate of growth because of India's unique demography; unlike other Asian economies, the country was a Hindu majority nation. Due to data sparsity, one can only point toward some potential factors that explain the decline of inequality during this period. I link it to the same policy environment within which Indian economic growth stayed repressed. The state introduced several measures that restricted, expropriated, and redistributed the rich's wealth. These measures include the progressive taxation of wealth and income, nationalization of several industries, land reforms, and industrial regulation. In a well-known instance of anti-elite populism during the early 1970s, and as a result of conflicts within the political leadership, India abolished special privileges ("The Privy Purse") extended to its aristocratic classes. There was also a spontaneous redistribution of wealth, triggered by inflation. Overall, when also considering the remarkable obsolescence of "old wealth", India's 1950-1980 era had similarities to the decline of the patrimonial rich classes in Europe during the first half of the twentieth century (Roine and Waldenström, 2015).

This article's data computations are, to the best of my knowledge, a first attempt to estimate top wealth shares for India during this period. And these are without doubt the only annual series that try to estimate wealth concentration for any time frame of Indian history. To construct top wealth shares, I exploit the stream of progressive tax schemes that were set up during the early independence years. In particular, my benchmark data are derived from estate taxes (i.e., taxes on large bequests). Estate taxes were applied in India between 1953 and 1985. After 1966, the tax authorities began publishing annual reports on the assessment of estates. Applying a uniform estate multiplier model, I infer the wealth of the living population using those estates that were large enough to become liable for estate taxation. As a resource to approximate and measure inequality, these estate tax returns have advantageous features that other fiscal data do not. For example, estate taxes did not exempt agricultural property. Other direct taxes in India, including income taxes that economists use to measure top income shares, give exemptions to agricultural incomes and wealth. Additionally, the procedure for filing estate taxes made

1 While national income grew annually at 3\%-3.5\% on average, the World Bank's estimate of per-capita incomes suggests only $1.1 \%$ growth per annum between 1960-1980. These growth rates were far lower than those in other comparable Asian economies. 
it less prone to evasion. Consistent fiscal data on large wealth holdings - such as these estate tax returnsalso overcome well-known deficiencies inherent in existing ${ }^{2}$ self-reported surveys. I discuss these issues in some detail in Section 2 of this article.

It is important to state from the outset that the results produced using these tax data have limitations. They require several assumptions and all computations are sensitive to the estimation method - the estate multiplier in this case. For example, I assume that the distribution of wealth among the living closely tracks the distribution of wealth among decedents. Even in countries where multiple historical data are available to compute wealth shares, the underlying method $\$ 3$ can produce different results. Ultimately, these data are a unique resource, perhaps best reinforced by the fact that estate and wealth taxes are no longer collected. Thus there are no comparable series that can extend my series into twenty-first-century India. The data's trends should shed some light on how and why wealth evolved in this critical juncture of Indian history, but their imperfections necessitate that they are not the final word. The interested reader can access all replication files and raw series online at the link provided in the appendix.

The remainder of this article is organized as follows: in Section 2 I briefly introduce the data and methods used to compute top wealth shares in this article. In Section 3 I contextualize the environment and social position of the rich around the time my analysis starts. The central results are laid out in Section 4 , and the subsections discuss explanations for the main trends. The last section concludes. A supplementary appendix contains replication guidelines and a link is provided to access the summary spreadsheet file - IndiaTopWealth.xlsx — which lists all the final data and tables used in this research.

\section{Data sources and estimation}

Approximating top wealth shares requires reliable information about the very rich. Survey data are not ideal for estimating the size and distribution of wealth among the very rich due to non-response rates of the rich and top-coded sampling strategies (Davies and Shorrocks, 2000). In principle, more representative data could be extracted instead by using returns from taxes on net worth (such as a wealth tax). For example, returns from progressive income tax tabulations have been employed generously to measure top income shares. However, taxes on net worth are less common, and the reliability of wealth tax data is uncertain; fiscal definitions of what constitutes wealth tend to fluctuate over time. And unlike at-source deduction of incomes, these taxes rely on self-reporting, which also increases the likelihood of evasion.

2 Household balance sheets are produced by the National Sample Survey Organization (NSSO) on a decennial basis since 1981 (all India) and 1961 (rural only). Part of the weakness of these surveys (as is with most wealth surveys) is the high non-response rate of the rich. Studies do exist that work within the tradition of the national sample surveys to assess wealth and socioeconomic deprivation. See, for example, Zacharias and Vakulabharanam (2011) and Anand and Thampi (2016).

3 See, for example, the comparison in estimates using surveys, investment income capitalization, and estate multipliers in Saez and Zucman (2016) for the US. 
So, not surprisingly, and with the exception of Scandinavian countries, top wealth shares are rarely ${ }^{4}$ computed from wealth tax returns.

In fact, studies of long-run (or historical) top wealth shares tend to prefer the use of estate tax returns (Piketty et al., 2006, Atkinson, 2008; Roine and Waldenström, 2015). Estates are the net wealth left behind by individuals at death. The advantage of using estate tax returns is that progressive estate taxation has a long history (Scheve and Stasavage, 2016), and its population unit (individual decedents) is fairly straightforward. Fiscal definitions tend to be consistent, and because these estates entail claims on inheritance - such as division of the property among heirs - there is a built-in mechanism for disclosure. Therefore, the challenge is to apply an appropriate estate multiplier 5 to estimate the wealth of the living. The idea behind this strategy is that "death selects a sample," which then gets recorded in estate tax returns. To reconstruct the wealth of the living population, the decedent's estate is "multiplied" by the inverse of the mortality rate $m$. For example, suppose the wealth of a decedent is Rs 50,000 and the mortality risk among the rich is $1 \%$; then this individual stands in for $1 / 0.01=100$ individuals, whose average wealth is Rs 50,000. The best (unbiased) approximations are usually made with unit-level estate files ${ }^{6}$ so that the age $(a)$ and gender $(g)$ profile of decedents match specific mortality rates $m_{a g}$.

The Indian government levied a full range of taxes on personal wealth - estates (bequest), wealth (net worth), and gifts (wealth transfer) - between 1953 and 1991. The 1953 Estate Duty Act was the first major direct tax on wealth in independent India and was followed up with wealth and gift tax acts in 1957 and 1958, respectively. The annual statistics regarding these taxes were published as reports in the All India Wealth Tax, Gift Tax and Estate Duty Statistics (AIWGE) between 1966 and 1991. I digitized these reports into excel files (see Appendix A); unfortunately, these reports are tabulations as opposed to unit-level data. For each year, the number of returns are listed against increasing intervals of the fiscally defined wealth category. Accordingly, the cumulative frequency of returns above any wealth cutoff can be estimated from these tables.

\subsection{Data}

In this subsection, I describe how the estate tabulations were converted into top wealth shares. Details on the Estate Duty Act are provided in Appendix B. The following are important definitions to keep in

\footnotetext{
4 Atkinson (2008), for example, cites large anomalies in estimates made using German wealth tax data. In fact, even Scandinavian (Norway and Denmark) estimates appear to have these anomalies. Some authors have employed wealth taxes successfully under different contexts. Alfani (2017) uses property taxes (which are, in essence, a tax on immovable wealth) to produce wealth inequality estimates for pre-modern periods of European history. A comprehensive taxonomy of cross-country data and methods on top wealth shares (and patterns) is discussed by Roine and Waldenström (2015).

5 One of the oldest applications of the estate multiplier goes back to Mallet (1908). Atkinson and Harrison (1978) employ estate files to estimate top wealth shares for the UK, while Kopczuk and Saez (2004) do the same to compile the first long-run estimates for the US.

6 Piketty et al. 2006) use particularly exceptional data since the French estate tax applied to a very large fraction of the population and was stored as detailed micro-files going back almost two centuries.
} 
mind: the relevant population unit for estates is the individual decedent, with wealth defined exactly per fiscal definition for tax purposes (i.e., the net principal value of the estate).

Each estate included 7 movable property (in India or abroad) and immovable property situated in India. Exemption levels were high and were meant to target only the very rich. Initially, in 1953, only estates above Rs 150,000 were liable, but the exemption limit came down to Rs 50,000 by 1964 . To add context, Rs 50,000 was worth almost 100 times the gross per-capita national income (Rs 540) in 1964. Estate duty was the sole direct tax scheme in India that did not exempt ${ }^{8}$ agricultural land. Since exemption limits were relatively high, it was expected that no small farmers would come under its purview. The principal value of the estate (net of liabilities) was calculated on the basis of market values at the time of death. Unlike other taxes, estate filing was costly for the tax authorities because it did not rely on self-reporting and random audits.

Given the small number of eligible estates, tax authorities assigned a "controller" per case to estimate market values ${ }^{9}$ of all eligible personal properties. Valuation was costly; roughly $50 \%$ of estate valuations were settled through legislation (Khan, 1986). Gifts made within two years of the estate holder's passing were also counted in the principal value of the estate. Top marginal tax rates stayed fixed from 1964 onward. Due to these fixed rates, with inflation and time, (a) smaller estates became liable for estate taxation and (b) the relative burden on larger estates increased with time (Figure 1). Eventually, the effective costs of administering estate duty became too high; mortality rates were declining in India, and revenues were assessed to be too low to justify the tax. Estate duty was therefore abolished in 1985 by parliament.

Comparisons with returns from the Wealth Tax Act were also used; Appendix B.1 contains comparative series using estate and wealth tax returns. The Wealth Tax Act applied to tax units and was only charged on unproductive assets. Due to (a) evasion, (b) frequent changes in fiscal definitions, (c) self-reporting and valuation, (d) exclusion of agricultural wealth, and (e) higher exemption limits (Rs 100,000), these data are much more problematic (Acharya, 2005). At the very least, estate tax returns provide a much higher population coverage (Figure 2), better capture the richest few Indians (fatter extreme upper tails; see Appendix Figure B.1), and importantly, keep consistent fiscal definitions of wealth throughout the period of analysis.

\footnotetext{
7 Movable assets comprised government securities, equities, cash and time deposits, life insurance proceeds, business interests, jewels, and some household goods (with exemptions). Immovable assets counted real estate and agricultural land. Proceeds from the sale of the decedent's property were counted under the principal values of the estate.

8 States were in charge of assessing and obtaining taxes from agricultural property, while the central government was in charge of movable and urban immovable property. Starting in 1982, a few states decided to stop charging estate duty on agricultural property.

9 Clause 36 of the Estate Duty Act: "The principal value of any property shall be estimated to be the price that, in the opinion of the Controller it would fetch if sold in the open market at the time of the deceased's death."
} 
Fig. 1 Average effective estate tax rates and bracket creep

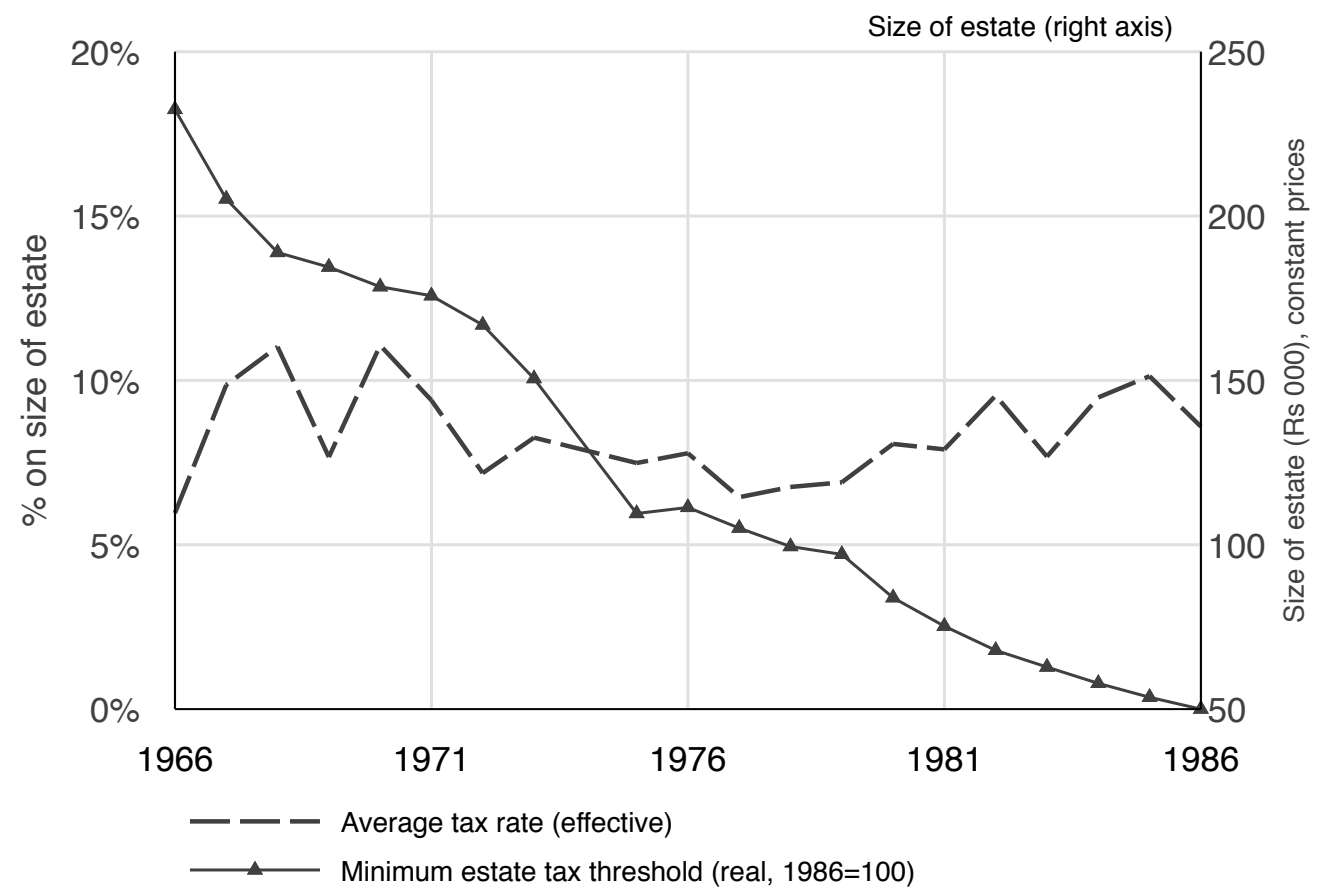

Author's computations using Table 18 in IndiaTopWealth.xIsx

To reconstruct the living population from estate tax returns, I apply a uniform estate multiplier using adult mortality rates $10(m)$ for India (i.e., each tax return in year $t$ is multiplied by $1 / m_{t}$ to approximate the living population at equivalent wealth levels). This method was necessitated by the data constraint; in the absence of unit-leve 11 data, concerns about the use of a uniform multiplier had to be relaxed. Obviously, this reconstruction is not ideal, but systematic biases would only be acute if the wealth of the entire population was being approximated $\sqrt{12}$ using a uniform multiplier. Since my data only count the rich, the respective issues (differential mortality, age-wealth gradient) are of lower priority. I discuss the problems of the uniform multiplier, including checks with alternative mortality rates, in Appendix B.2. An admittedly sparse comparison of the wealth of the living and rich was attempted using wealth tax returns (living tax units) and estate tax returns (individual decedents) over the relevant time period. Overall, I find no systematic or anomalous bias between the bulk of these two distributions (Appendix Figure B.1.

\footnotetext{
10 Annual adult mortality rates were downloaded from the World Bank Open Database.

11 Based on informal conversations with tax authorities, there appears to be no probability of estate micro-files being published in the future.

12 See Atkinson (2008) for the validity of a uniform multiplier when the intention is only to estimate the richest fractions of the population. If wealth shares for the full population were being reconstructed, then increasing lifetime disparities between the poor and the rich would overestimate inequality. Within the rich, the issue is not so severe, and high exemptions on estate taxes automatically select only the rich. For France, Piketty et al. (2006) finds almost no impact on trends in top wealth shares when using uniform multipliers.
} 
Fig. 2 Corresponding populations captured under estate and wealth tax codes

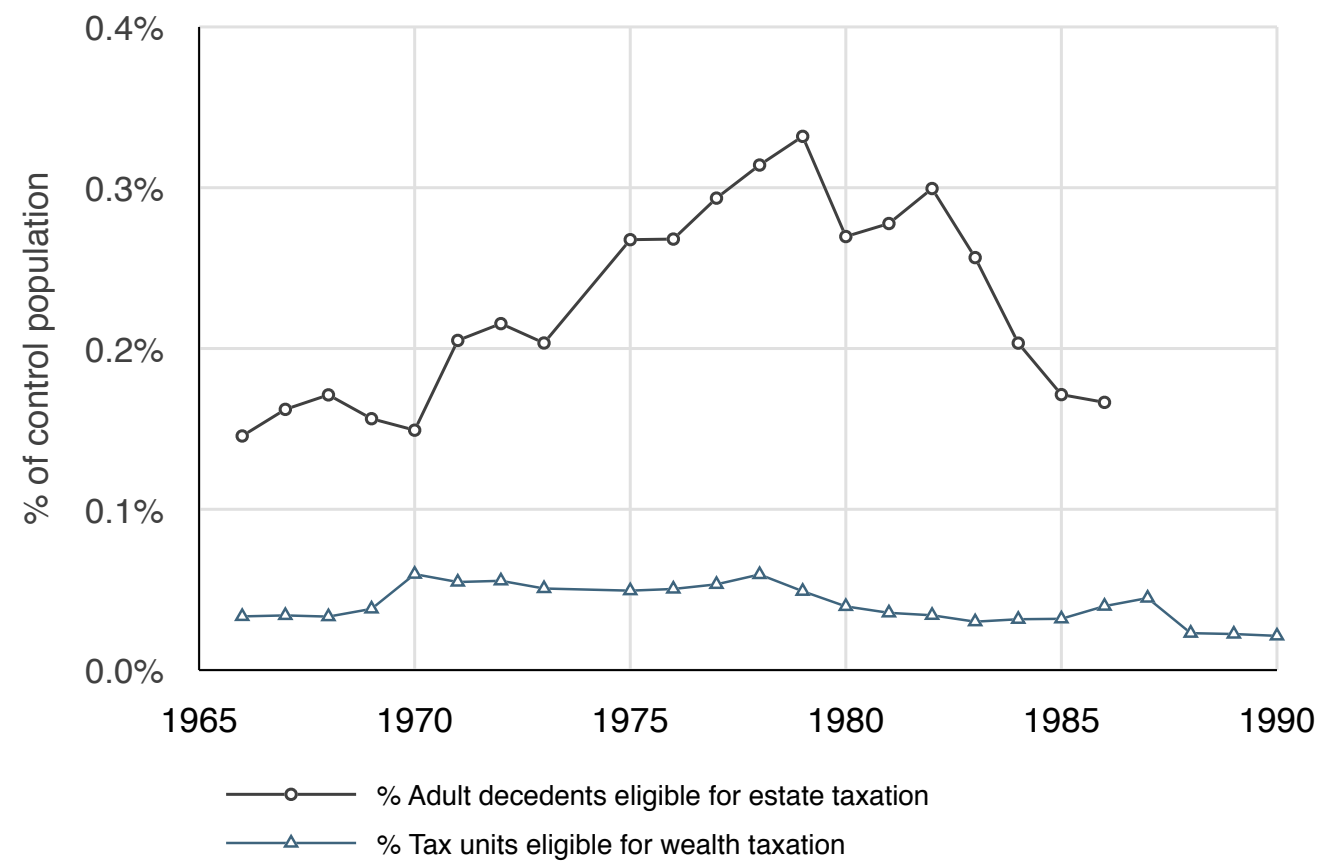

Author's computations using Table 11 in IndiaTopWealth.xlsx

\subsubsection{Estimation of top wealth shares}

The estate multiplier translates the adult decedent ${ }^{13}$ population into living individuals organized by wealth size. Thereafter, these individuals are taken as a fraction of the adult population, and wealth cutoffs for precise percentiles (p99, p99.9, p99.99, etc.) are computed by Pareto interpolation. These techniques follow the same estimation strategy employed by Piketty (2003) and Kopczuk and Saez (2004) for tabulated estate tax returns. All estimates appear in Tables 1-7 of IndiaTopWealth.xlsx.

Using average wealth and total individuals above the top percentiles, I compute the total wealth held by the top $1 \%$, top $0.1 \%$, and top $0.01 \%$ (including intermediate fractiles: p99-99.9, p99.9-p99.99, etc.). Last, to convert these aggregate into top wealth shares, I develop control totals for personal wealth. Since the official Indian statistical agencies do not publish ${ }^{14}$ household balance sheets, personal wealth needs to be approximated. Accordingly, I use the Harrod-Domar-Solow steady state formula $\beta^{*}=\left(W_{p} / Y\right)^{*}=s_{p} / g$, where $W_{p}$ is personal wealth, $Y$ is national income that grows at rate $g$, and $s_{p}$ is the personal savings

13 In the estimate of adult decedents, only individuals at or above the age of 30 are counted. This assumption is made to (a) account for the likelihood of death, which is much lower for adults between 18 and 29 , and (b) to approximate the population holding positive wealth.

14 The NSSO started surveys in 1981 to make decennial estimates of household balance sheets (1991, 2002, 2012) at the all India level. But given that they miss the rich, these surveys are likely to produce downward-biased estimates. This bias is most evident in NSSO estimates of per-capita growth of consumption, for example. These surveys miss a significant chunk of growth estimated in the national accounts for the 1980s and 1990s. Partly, this puzzle is the motivating point of departure in Banerjee and Piketty (2005). 
rate. Taking quinquennial averages of the savings-growth ratio $\left(s_{p} / g\right)$, personal wealth is computed as a product of annual $Y$ and $\beta^{*}$. All macro-series were obtained from the Reserve Bank of India, and real aggregates were computed using the GDP deflator.

These methods highlight that several assumptions were built into the construction of these series. To summarize, according to my series, top wealth shares among decedents were equivalent to top wealth shares among the living. While clearly an imperfect approximation, these series at least help make progress on the potential trajectory for wealth concentration (and inequality in general) during an important phase of Indian history. Appendix B.3 lists the main limitations that should be kept in mind when looking at the results.

\subsection{Comparison with Banerjee and Piketty (2005) data on income concentration}

The strength of these estate statistics becomes easy to see when considering stylized facts on inequality for India. Banerjee and Piketty (2005) use income tax tabulations with the same estimation strategy (Pareto interpolation) to compute top income shares from 1922 to 2000. Subsequently, the series was updated to 2015 by Chancel et al. (2018). Both estate and income tax returns were published annually between 1966-1986, thereby putting them in a unique class of comparable fiscal data.

In many ways, estate statistics provide more robust information than income tax returns. First, estates have a well-defined population since estate duty applies to individuals, whereas income taxes are charged on tax units that (in the absence of actual data) require stronger assumptions to approximate the control population. Second, estates have better coverage because they include agricultural property; income taxes exempt agriculture-related incomes. A majority of India's population is still dependent on agriculture, so landholdings are always an important source of inequality (Rawal, 2008). Third, when the estate tax was operational in India, it had a well-defined administrative division dedicated to evasion and valuation, whereas a large set of income tax returns relied on self-reporting with randomized official scrutiny. Since, by definition, estates applied to a fraction (decedents) of a fraction (the rich) of the population, the probability of scrutiny was much higher anyway. Finally, income taxes are the only data on income inequality in India, thereby excluding the possibility of comparison. Estate taxes between 1966-1985 can be sorted on quality as superior among one of at least two fiscal sources (wealth taxes being the second) and potentially even if one is including survey type sources (only rural, infrequent, and top-coded).

\section{Historical background and India's elites}

\subsection{Colonial era inequality}

To contextualize these series, it is important to understand whether the rich had been prospering in the periods preceding the Hindu growth years (i.e., the late colonial period) or if the decline had already set in earlier. It is important to remember that economic growth had stagnated and poverty had magnified over 
the interwar period (1919-1939) in colonial India (Sivasubramonian, 2000). But from various indicators, it appears that this stagnation was not detrimental to at least a fraction of the population. First, as per the calculations of Alvaredo et al. (2017), top income shares had peaked over the first half of the twentieth century. Second, real non-wage incomes did rise between 1900-1946 (Roy, 2002), so while poverty was creating losers, there were also some winners in the colonial economic environment. Importantly, only a very small fraction of these winners could potentially be British colonialists because of their insignificant share of the population. From social compositions and the correlations of income shares, Maddison (1971) and Alvaredo et al. (2017) conclude that the rich classes of late colonial India were predominantly Indians. The key point is that the inequality that existed in the first half of the twentieth century had no reason to dissipate spontaneously with the exit of colonialists.

The existence of an indigenous class of elites in a colonial society closely corresponds to the AcemogluJohnson-Robinson (AJR) hypothesis (Acemoglu et al., 2002). In their theory of the reversal of incomes, AJR proposed that, for countries such as India, the institutional setup prior to colonialism was skewed in favor of a small (but powerful) fraction of rich landlords or aristocratic rulers who would enforce only their own property rights. For a separate set of entrepreneurs, the absence of such rights would limit their potential to deliver transformational growth and industrialization. The colonizers reinforced this institutional equilibrium and used the incumbent model of tributes to extract surpluses. In this environment, wealth stayed concentrated, only being transmitted within the pre-existing rich classes.

The AJR model does seem to fit Indian society in the colonial era. In particular, most attention has usually been paid toward the landlord class (zamindars) that gained from institutions of land tenure ${ }^{15}$ in colonial India (Banerjee and Iyer, 2005). Since the zamindars were relatively numerous, they typified the prototypical feudal elite, appropriating political privileges and securing their property rights. While the British colonial administration controlled much of the Indian subcontinent, around 30\%-40\% of the region was directly ruled by a native princely class (Ramusack, 2004). These princes (around 560-570) and their territories coexisted with British India but operated independent of colonial policy. As hereditary rulers of their states, the princely class enjoyed the highest degree of political privileges. Through inheritance, they had amassed sizable fortunes over time and certainly were many magnitudes richer than most inhabitants of the subcontinent. The rulers of the states of Gwalior, Jammu and Kashmir, and Hyderabad were perhaps some of the richest dynasties in history. The ruler (Nizam) of Hyderabad, according to Time Magazine, was, in 1937, the wealthiest man on the planet.

Not all colonial inequality originated from India's feudal past. Some portion of the increase in inequality also reflected the improved fortunes of the indigenous capitalist class, suggesting that the institutional mechanism of the AJR model is incomplete because it proposed that feudal elites would oppose the emergence of such classes to quell any threats to their social positions. But colonialism also imparted its policies of keeping open factor markets and encouraging commodity trade. Within the last century

\footnotetext{
15 See also Roy and Swamy 2016 regarding the legal framework for land ownership and transfer.
} 
of British rule, India witnessed the rising importance of indigenous merchants and industrialists who capitalized ${ }^{16}$ on the laissez-faire attitude of colonial policies (Roy, 2016). Of special significance is the fact that despite an agrarian stagnation, secondary sector output was rising throughout 1900-1946 (Sivasubramonian, 2000). As ties between foreign and colonial markets began weakening after the Great Depression, leading players in this more modern segment of elites began to dominate industrial capital. Once the appeal of the international market began to fade, the leading industrial elites also became key players in financing and supporting the freedom movement.

\subsection{After independence}

These elite classes - feudal or industrial-remained in India after the British departed. But the prolonged spell of poverty and stagnation meant that by the middle of the twentieth century, there was a glaring gap between them and the rest of the population. Emancipating independent India's newly enfranchised population was essential to the momentum created by the freedom movement (adult suffrage was universalized in 1952). The existence of feudal institutions stood contrary to these ambitions.

Government attention quickly turned to addressing these social inequities. Their initial redistributive focus was on agriculture; a large mass of the electorate was situated in rural India. Landlordism was abolished in 1952, and notably, estate taxation also included agricultural land in its purview. A series of land reforms followed in the mid-1950s with a focus on setting ceilings on large holdings. For the aristocrats, a deal-making approach was adopted in the independence process itself. As part of the unification of India into one independent entity, the princely class was integrated through political alliances. Their territories were annexed into the Indian union; the effect was twofold in that they were no longer hereditary rulers of their territories and could no longer count much of their landholdings in their personal wealth portfolios. For this bloodless transition from aristocracy to democracy, they received $[17$ guaranteed stipends (proportionate to territory) from the government, as privy purses, to sustain their lavish lifestyles (Roberts, 1972).

The decline of meritocratic industrial wealth was more gradual. While measures such as progressive estate and wealth taxation had been implemented in the 1950s, the political class was also aware that redistributing wealth would possibly lead to distributing poverty (Parekh, 1991). The state's planning architecture instead aimed to approach redistribution by building a large public sector and using industrial regulation as a way to reverse the inqeuities perpetuated by laissez-faire colonialism. Interestingly, foreseeing the threat of foreign competition after independence, India's leading industrialists had devised measures ${ }^{18}$ to keep their influence intact. However, once the right-wing elements of the ruling Congress

16 See Roy (2018) for a detailed overview of the domestic business and merchant classes in colonial India.

17 The smaller, related feudal lords in erstwhile princely territory also received minor payments.

18 Fourteen industrialists, under the auspices of other political elites, came together and formulated the Bombay Plan in 1945. The "plan" outlined a domestic path to industrialization for newly independent India. 
party faded away in the mid-1950s, India's prime minister (Jawaharlal Nehru) became more forthright about his socialist vision of industrialization. Rail and air transport were nationalized, with key sectors, such as consumer provisions and public utilities, also under public domain.

These developments of the early independence years reflect the fact that the economic and political environment had become relatively hostile toward the established elite. State-led industrialization was seen as a way to lift up the masses, while institutional changes in rural society aimed to curb its feudal elements. Given the redistribution of rural land, the nationalization in industry, and the implementation of progressive taxes, wealth concentration around the mid-1960s (when my data starts) began to decline from its pre-independence levels. Thus the key break away from inequality had already begun, and the post-1966 series reflect the outcomes of an even more socialist turn in Indian history.

\section{Results}

A summary of key results is listed in Table1. The background trend to keep in mind is the annual growth rate of national income (3.5\% aggregate, $1.1 \%$ per capita) between 1950-1980. In Indian history after 1950, this period is characterized as unfulfilled growth expectations, the very basis of the Hindu rate of growth terminology. However, over a much longer timeline (the entire twentieth century), the 1950-1980 period still represents a very noticeable transformation: in growth rates relative to stagnation in the late colonial period, in terms of the institutional environment, and in terms of the post-independence emphasis away from agriculture and toward industry.

Table 1 Summary growth over 1966-80. Author's computations using Table 15, 16 in IndiaTopWealth.xlsx

\begin{tabular}{|l|ll|}
\hline $1966-1980$ & Growth rates (annual) & Growth factor $\left(x_{t+n} / x_{t}\right)$ \\
\hline \hline Population & $2.18 \%$ & $135.26 \%$ \\
National income (Real, 2017=100) & $3.10 \%$ & $153.33 \%$ \\
p99.9 threshold (Real, 2017=100) & $-2.27 \%$ & $72.46 \%$ \\
Wealth (Top 0.1\%, individuals, Real) & $-2.11 \%$ & $74.17 \%$ \\
Top 0.1\% wealth share & $-5.03 \%$ & $48.54 \%$ \\
Share price of all listed equities & $-0.48 \%$ & $93.48 \%$ \\
\hline
\end{tabular}


Fig. 3 The (d)evolution of the Top $1 \%$

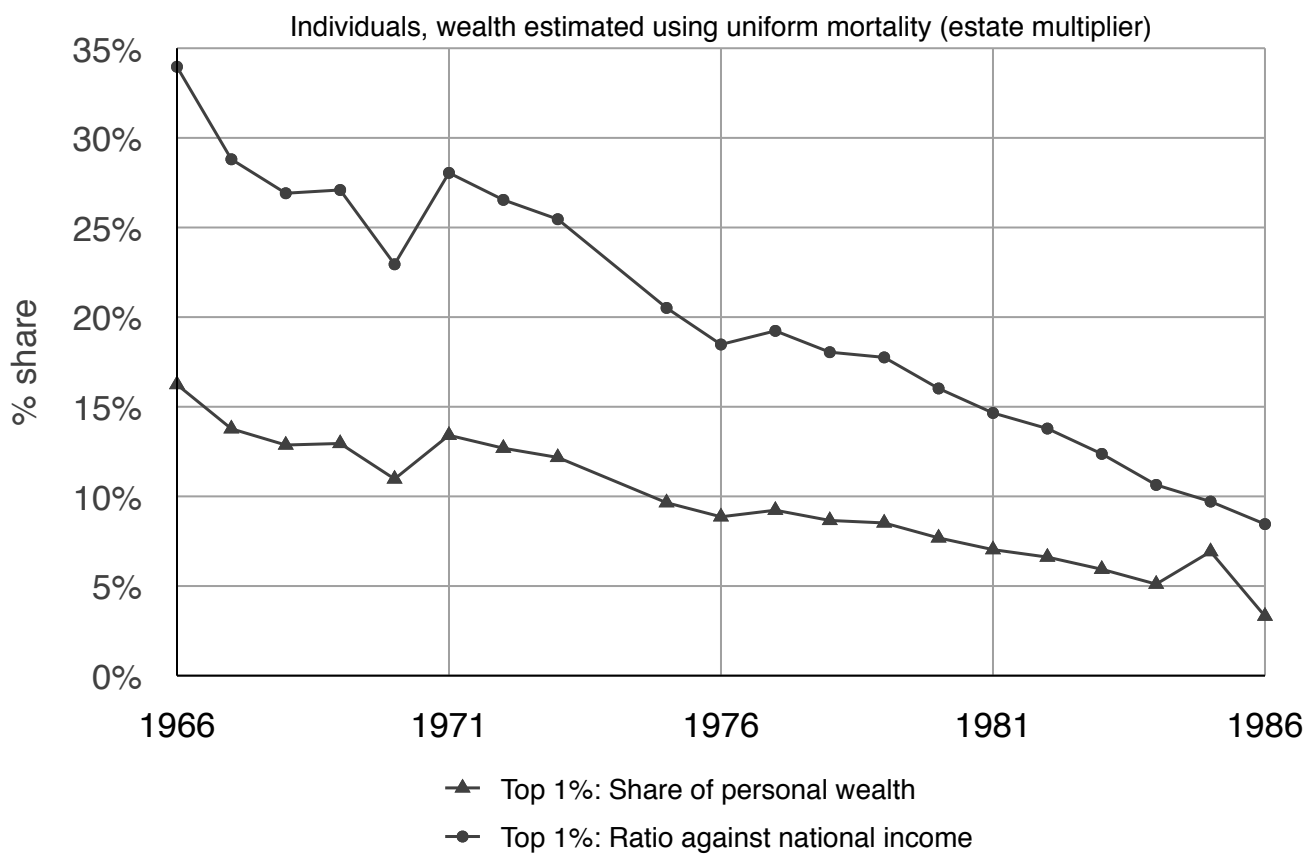

Author's computations using Table 6 in IndiaTopWealth.xlsx

4.1 Evolution of top Indian wealth shares: 1966-1985

Turning to the main series, Figure 3 shows the decline in top wealth shares from 1966 to 1985 . The share of personal wealth held by the top $1 \%$ declined at an annual rate of nearly $5 \%$ (Table 1 ). The early 1970s are a period of special interest, in terms of the magnitude of decline. In 1966 the top $1 \%$ wealth share was around 16\%. Even around 1971, a randomly selected individual in the top 1\% held wealth equivalent to 14-15 times that of the average Indian. But the trajectory turned downwards very visibly over the $1970 \mathrm{~s}$; by 1985 , the top $1 \%$ held only around a $6 \%$ share of personal wealth.

The magnitude of decline at the top was quite large. Three (not mutually exclusive) possibilities may have been at play. First, the richest were in fact losing wealth (discussed later). Second, newer entrants into the top $1 \%$ were not able to accumulate much more than the threshold in order to be counted above the 99th percentile. And finally, increasing wealth for those below the 99th percentile may have also cut into the top wealth share. Given that economic growth was occurring in India and savings were on the rise, surely some (relatively poorer) part of the population was getting wealthier. The second series in Figure 3 shows that the ratio of the top 1\%'s wealth against national income declined even more strikingly than wealth shares. Now, to make clear, poverty levels during this period were not trivial. Populationlevel inequality could well have increased due to appropriation of the wealth share by, say, those in the 80th to 99th percentile. However, such developments do not negate the decline at the absolute top.

One area that merits more investigation is the symmetry, or asymmetry, of wealth losses within the top 1\%. Did the decline of top wealth shares imply a consistent wealth leveling above the 99th percentile? Or 
did declines reflect certain fractions within the top 1\%? The share of intermediate fractiles (p99-p99.99) confirm that all subgroups within the top $1 \%$ experienced systematic losses in their wealth shares relative to aggregate personal wealth. The top wealth share decline was robust to the exclusion of losses for any of the intermediate fractions. But the effects were most pronounced above the 99.99th percentile, followed by the 99th percentile, and the least worst off (relatively) were those inhabiting the distribution above the 99.9th, but below the 99.99th, percentile. Thus, inequality within the rich declined slightly but it wasn't the central factor driving down top wealth shares.

Fig. 4 Annual inheritance flow from top $1 \%$ estates

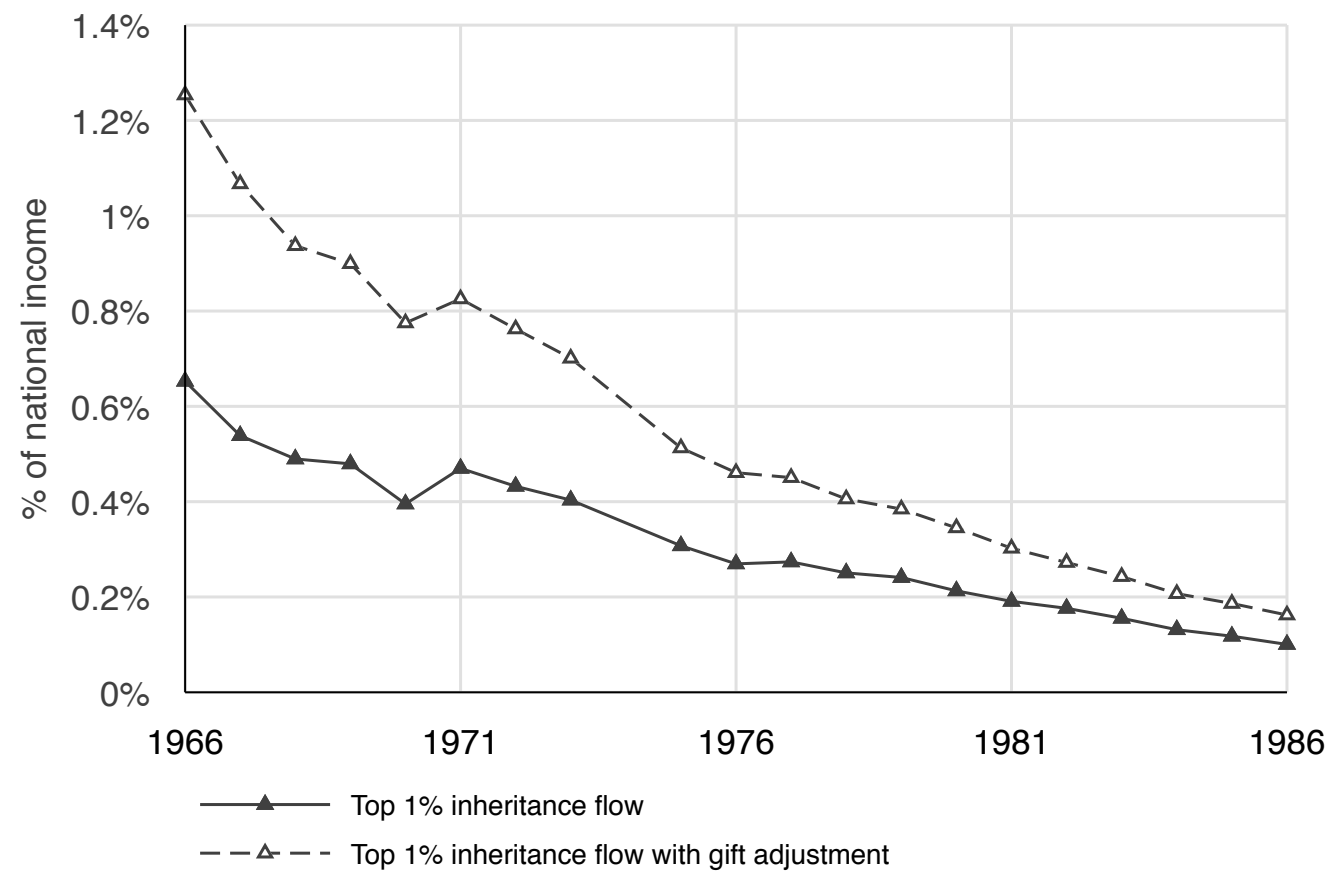

Author's computations using Tables $1 \mathrm{a}$ and 19 in IndiaTopWealth.xlsx

Finally, economic growth and inflation acted as important levelers of old wealth. Based on the timeline, a bulk of the largest inheritances between 1966-1975 were probably carried over from the colonial period. A low growth environment similar to the late colonial period (especially the interwar years) would have been ideal for the inheritors of past wealth. To think about this, imagine someone inheriting Rs 100,000 in cash and holding on to it through $0 \%-0.5 \%$ economic growth and no significant inflation before transmitting it to the next generation. The loss of purchasing power would barely register over an entire generation. But as previously stated, the Indian economy was undergoing a structural shift in its growth process, and inflationary episodes were frequent. Figure 4 shows the size of the richest $1 \%$ estates ${ }^{19}(\operatorname{pretax})$ as a ratio against national income. In this series it appears that the flow of inheritance 20 became almost

19 The second series in this figure adds Rs 50,000 to each estate to compensate for any inter vivos gifts (non-taxable up to that amount).

20 Inheritance flows depend on the number of decedents (mortality rates) and the size of personal wealth. Even if personal wealth is relatively small, a higher mortality rate can generate large annual flows of inheritance. Suppose, for example, that 
inconsequential by 1985. The takeaway is that not only were the rich unable to increase their wealth, but dynastic wealth from the past was also being expropriated by inflation and growth.

Fig. 5 Income vs wealth concentration: The Top 1\%

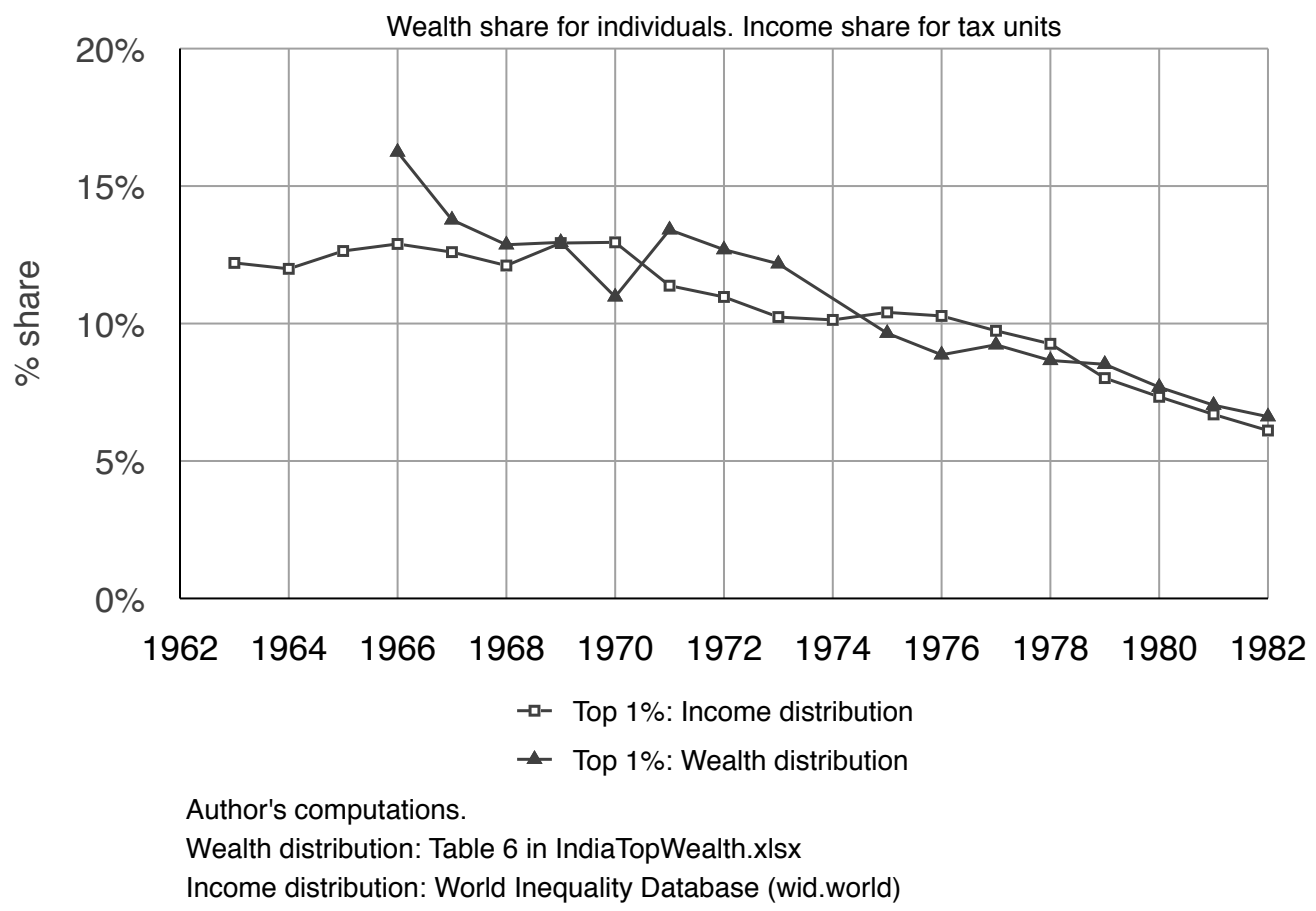

Next, I track changes in the upper tails of the income and wealth distribution. From Banerjee and Piketty (2005), we already know that the 1970s were also the period that saw the largest decline in top Indian income shares, at least in the twentieth century. The fact that wealth shares underwent a similar pattern are therefore more important, in terms of the historical transition. The size and trends in income and wealth concentration (top 1\%, top 0.1\%) are compared over 1962-1982 in Figures 5 and 6. What these series suggest is income and wealth shares for the (respective) top $1 \%$ became almost indistinguishable in the 1970s. On the other hand, wealth was more concentrated than income for the top $0.1 \%$, and this gap more or less persisted throughout during this period. The wealthiest $0.1 \%$ were 60 times richer than the average Indian in 1966 and around 30 times richer in 1982. For incomes, the top $0.1 \%$ were 15 times richer than the average tax unit in 1982 (40 times in 1966).

This pattern is not surprising because wealth tends to be more concentrated than income (Piketty, 2014). Nevertheless, the correlation in their trends is interesting and is suggestive in historical terms.

there are 100 individuals that own Rs 100 worth of wealth each. If the mortality rate during a given year is $10 \%$, then 10 individuals pass away, leaving Rs 1000 worth of total inheritance. If the mortality rate doubles to $20 \%$, then the size of inheritance also doubles. From Table 4 in the database file IndiaTopWealth.xlsx, I find that the decline of mortality rates between 1970-1980 had a small impact of wealth shares. This impact was less than the shrinking size of personal wealth itself. 
Fig. 6 Income vs wealth concentration: The Top $0.1 \%$

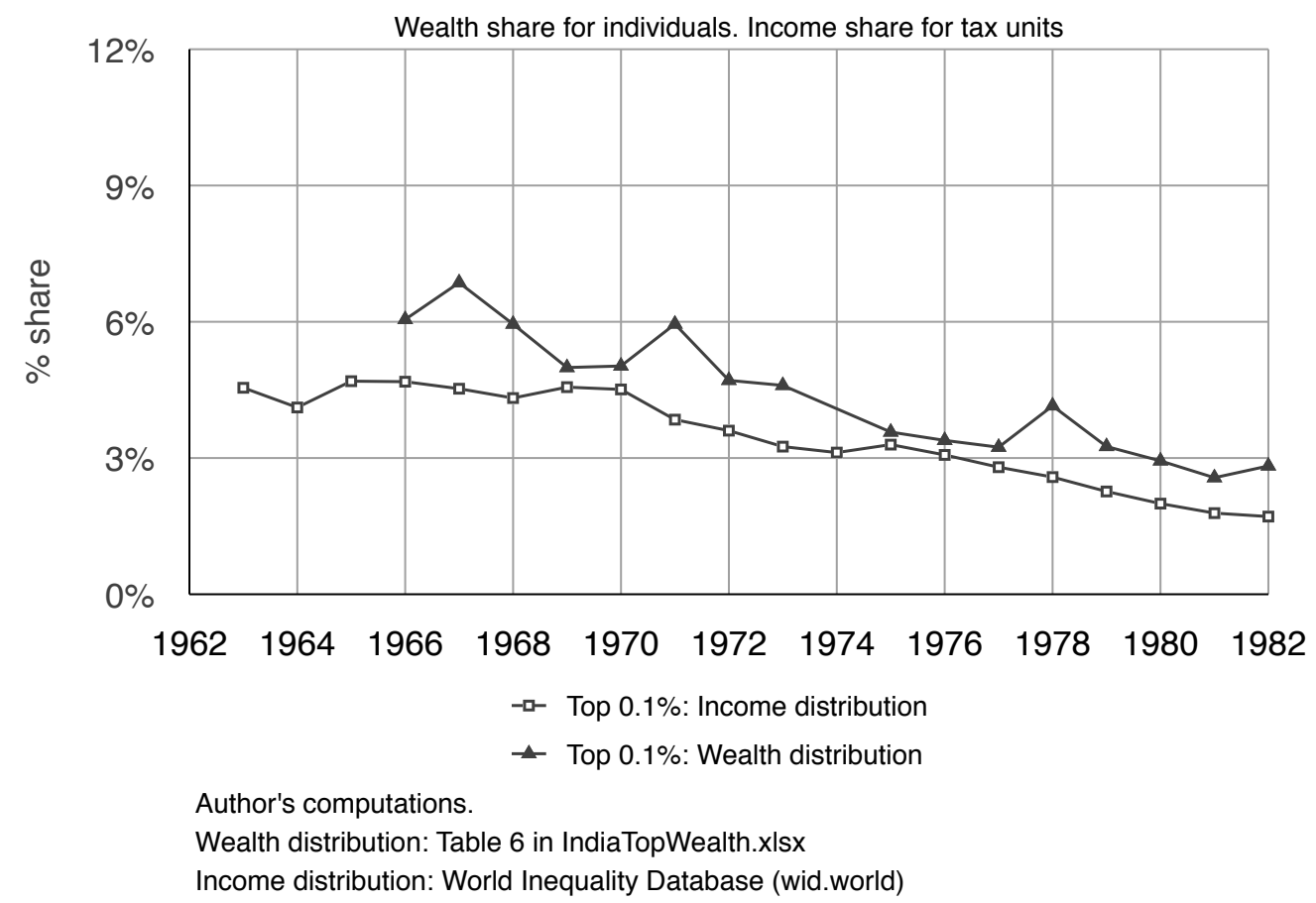

Note that for India, this is the only period where we can actually see simultaneous annual trends in both top income and wealth shares. And based on the historical context, these data can help connect India to what is known about the rich elsewhere.

4.2 Was lower income concentration rooted in wealth?

Such one-time expropriations of society's incumbent elites are reminiscent of other historical instances of declining income concentration. Particularly when looking at Europe around the early twentieth century, certain patterns stand out. Top European shares descended rapidly between 1910-1945, a period that coincided with the relative expansion of adult suffrage and the adoption of progressive taxation (Roine and Waldenström, 2015, Scheve and Stasavage, 2016). Amplifying these institutional changes were financial crises brought about by the depression and capital destruction during the two world wars. Prior to this period ${ }^{21}$ Europe's patrimonial wealthy classes were distinguished by their near total control over capital income. They derived incomes such as rents on real estate, interest on bonds, etc. As their wealth holdings came down, lower capital incomes followed ${ }^{22}$ and thereafter so did income inequality.

21 Over the early modern period, for many parts of Europe, the class bifurcation between the rich and the rest became very explicit. See Alfani (2017).

22 In the case of France, for example, Piketty (2003) notes that wages were fairly stable through 1910-1970. The spontaneous fall of capital income, due to the collapse of wealth at the top, was the primary determinant of the decline in French income inequality in the first half of the twentieth century. 
Banerjee and Piketty (2005) also hypothesize a similar process (i.e., a decline in top capital incomes during 1950-1980 as the driving factor for the fall in Indian income inequality). This hypothesis is in fact reinforced 23 by the joint downward trajectory of top wealth and income shares. Remember that expropriation of existing wealth (nationalization, redistributive land reform, etc.) started quickly after independence. Therefore it is not too sanguine to expect a leveling effect on capital income. The high losses borne by the super rich (top $0.01 \%$ ) had to have impacted the corresponding capital income flow. There is little to suggest that India's feudal elites - whose wealth was derived from special property rights - had the entrepreneurial know-how to substitute rents or tributes they previously enjoyed under colonialism. Dilution of those rights effectively hit at the root of the non-labor share of national income. For the broader class of rich (including industrialists), the rise of public ownership of national capital was fairly crucial. Public capital became the foundation for industrial policy in newly independent India. By definition, such new forms of capital would not produce private capital incomes and so could not contribute to pretax income inequality. One could argue that under different circumstances (privatedriven industrial growth, pro-business policy environment), there may have been a sufficient flow of profits to mitigate the decline in capital incomes.

4.3 International comparisons: top wealth and income shares

Fig. 7 Top $0.1 \%$ wealth shares: India, USA and France

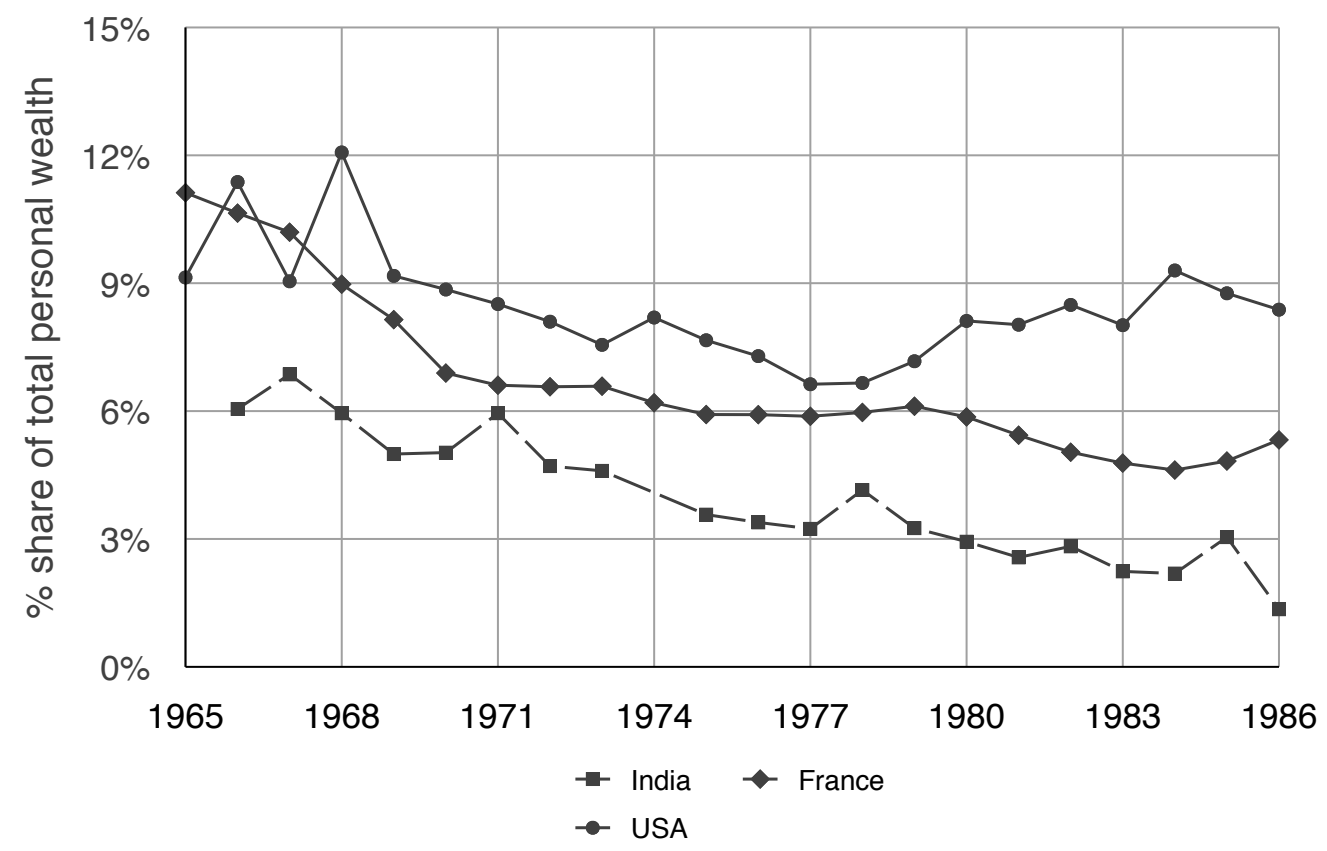

Wealth shares for France, USA from World Inequality Database (wid.world)

Wealth shares for India are author's computations using Table 14 in IndiaTopWealth.xIsx

\footnotetext{
23 Existing tax based tabulations do not allow any analysis of the composition of income for any group. But supplementing downward trends in top income shares with simultaneous shrinking of top wealth shares serves as a fairly good proxy for a fall in top capital incomes.
} 
Fig. 8 Top $0.1 \%$ income shares: India, USA and France

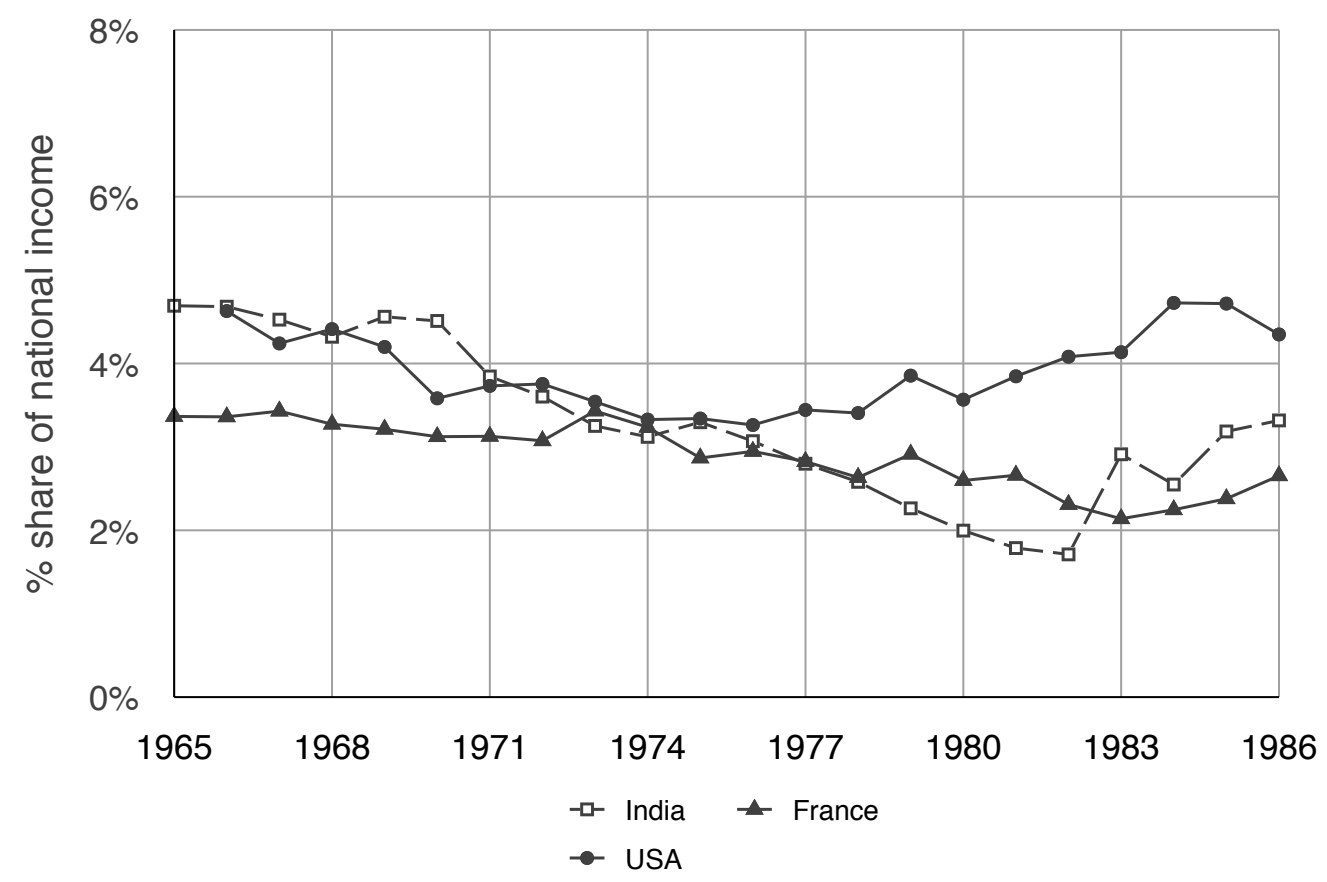

Source: World Inequality Database (wid.world)

How did India's rich compare to those elsewhere during the same years (1960-1985)? Figures 7 and 8 show top wealth and income shares, respectively, for the top $0.1 \%$ in India, France, and the US. Although this period was marked predominantly by a decline in each of these countries, Indian wealth was less concentrated (3\%-6\%) than the latter two (6\%-9\%). The post-independence decline in top Indian wealth shares was actually comparable to Western trends of the 1910-1945 period, when large fortunes had nearly disappeared (Piketty, 2014). And at least in the US, top shares had begun their recoveries in the late 1970s. One key supporting element here is the effect of reduced capital income concentration. Income concentration in India started out higher than French levels but quickly collapsed in the late 1970s - simultaneous to the wealth share decline. For rich Europeans and Americans, the post-war years were a struggle to rebuild their fortunes under high tax rates. Their capital income collapse had already occurred during the interwar period; income shares did not dramatically decline the way they did in India 24 between 1966 and 1980.

\subsection{Did evasion matter?}

The magnitude of these declines at the top are quite striking and place the 1970s as the largest leveling of top income and wealth shares in twentieth-century India. A common concern with fiscal data is that such downward trends could potentially emanate from rising evasion. But can evasion sufficiently explain

24 One key development of the period was excessive bureaucratic recruitment at inflation-indexed salaries (Salvatore et al. 2000). Accordingly, the entry of these elite bureaucrats may have usurped some of the top 1\%'s income share away from the top $0.1 \%$. 
the decline of the top $1 \%$ wealth share from $16 \%$ in 1966 to $5 \%-6 \%$ by 1985 ? By looking at the source data (top estates, Figure 91, it is evident that nominal reported values of wealth among the richest decedents were increasing every year. If evasion was rampant, then one should have expected a stall, or even decline, in the reported values of these estates. Second, this would require a deterioration in tax authorities' technology for scrutiny. But even here, these doubts are limited by the administrative working of the estate tax. These valuations were (a) not based on self-reporting; (b) the smaller population of rich decedents were ensured assigned case officers (instead of a random audit) per estate; and (c) certification for ownership was mandatory for inheritors to claim inherited wealth. Therefore there is sufficient merit in the claim that a dramatic reduction in wealth concentration in India did occur in India during these years.

Fig. 9 Size of wealth: Top 1\% decedents 1966-86

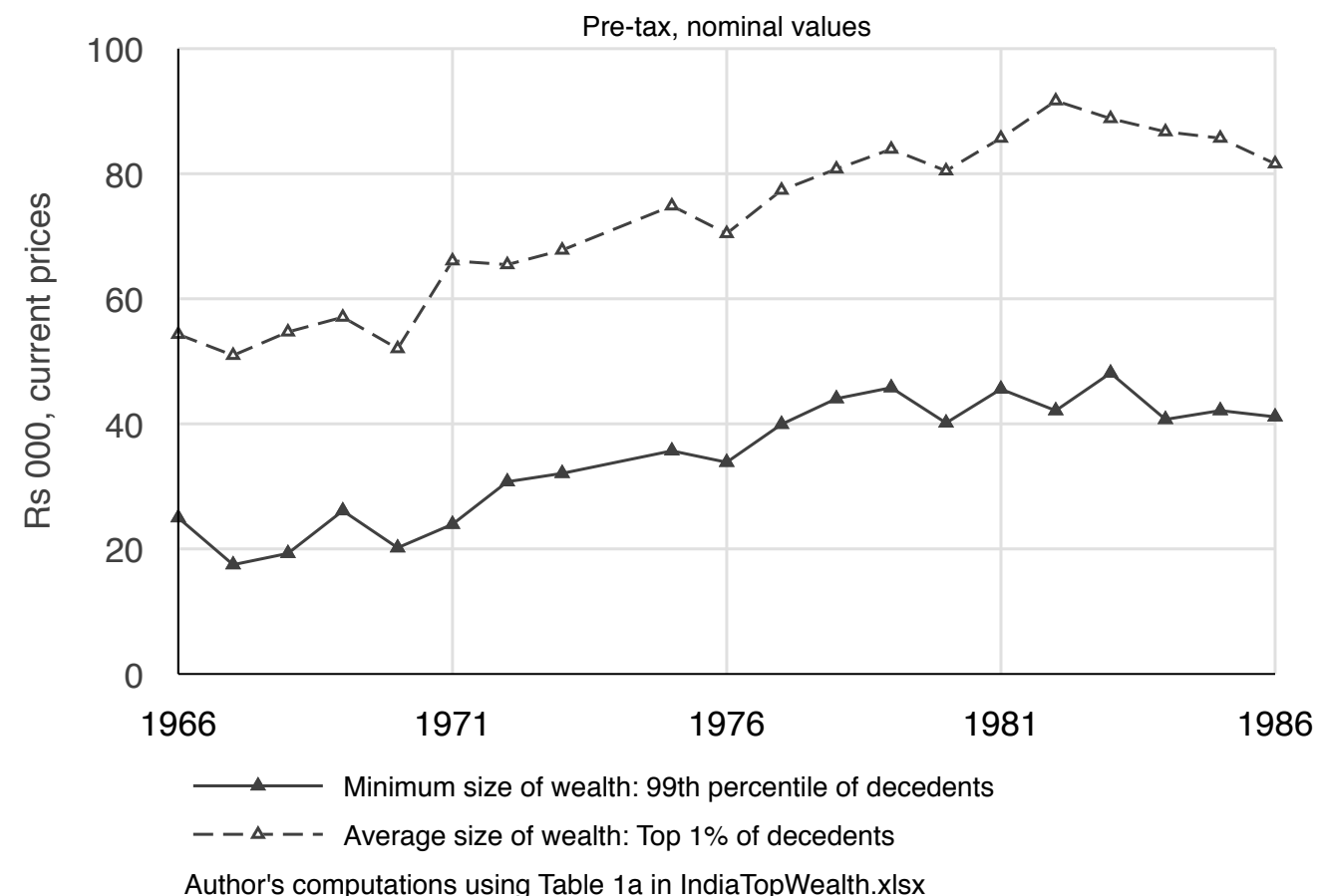

4.5 The historical facts behind the decline of the Indian wealth share

The demise of top wealth holders in India during the 1960s and 1970s is consistent with the historical legacy of politics and economic policy during that period. The amplification of existing inequality in late colonial India stemmed from low economic growth, concentrated political rights, and deregulation of private capital; nearly all of these features were reversed after independence. Starting in the 1960s, the socialist rhetoric of political leaders intensified. Progressive taxation became steep and nationalization and inflation expropriated private wealth. And last, but crucially, explicit steps were taken to end the special rights and powers of past royalty. 
4.5.1 Asset prices and corporate decline

Fig. 10 Size of real wealth: Richest decedents 1966-86

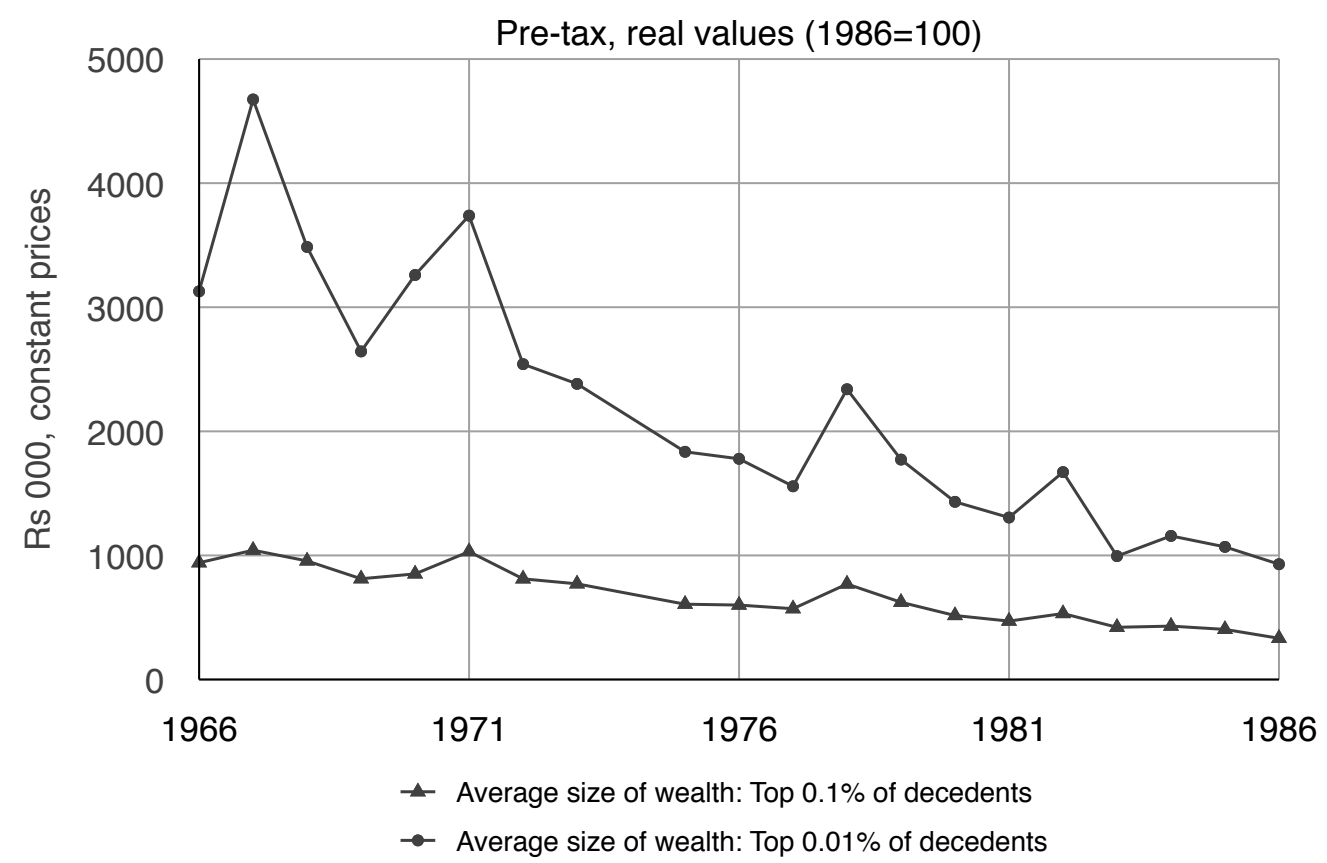

Author's computations using Table $1 \mathrm{~b}$ in IndiaTopWealth.xlsx

Figure 10 looks directly at the value of the richest estates (i.e., only decedents) in India (top 0.1\%, top $0.01 \%$ ) at real prices and shows that inflation cut the net worth of these estates quite significantly. By 1980, the value of the top $0.01 \%$ pre-tax bequests came to down to a fifth of their 1966 value when taken at constant prices. While real leveling was lower for the top $0.1 \%$ estates, it was still powerful enough to cut real wealth in half by the 1980s. Was the inflation-adjusted decline of top wealth holders spontaneous or was it triggered by the policy environment? The data are too limited to tease out robust causality, but the political economy of the 1960s and 1970s was hardly appropriate for asset price growth. While there were quantitative expropriations (through taxes or nationalization, discussed next), there were also revaluation effects that redistributed wealth away from the rich. In a society where certain classes of assets (such as equities in corporations) are highly concentrated, a deviation between consumer price inflation and such asset prices can lead to a redistribution ${ }^{25}$ of wealth. For example, if corporate ownership is concentrated and inflation outgrows stock prices, then wealth is automatically redistributed against the rich. Note that land reforms had already put a ceiling on the size of holdings, thereby reducing the attractiveness of investing in large rural swaths of land. However, the downward trajectory of real wealth at the top was also supported by the evolution of equity prices.

\footnotetext{
25 See, for instance, the case of French inheritances during the interwar period (Piketty, 2011$)$.
} 
Figure 11 shows a times series of real equity prices. These series track the equity price index adjusted for the GDP deflator (with 2017 equal to 100). Downward trends imply that equity prices were unable to keep up with inflation. As the data suggest, the expropriation of corporate net worth via inflation was strongest during the 1960s and 1970s, and such expropriation obviously reduced the net worth of the owners of these equities. Corporate declines were rampant in this period. Actually, the tide had turned against private business in the late 1950s - India's second Five-Year Plan (1956-1961) explicitly outlined a "socialist pattern of industrialization" that sidelined the growth of private corporations. A separate institutional decline also set in for larger corporations that had originated in the colonial period (Roy, 2017). Many companies either went bankrupt or were nationalized; therefore the capitalists who had built up wealth in the late colonial period were, as a whole, facing a reversal in fortunes. And since the stock market saw very limited participation to begin with, the downturn meant wealth was being redistributed (by prices) in favor of the rest of the population.

Fig. 11 Evolution of equity prices in India

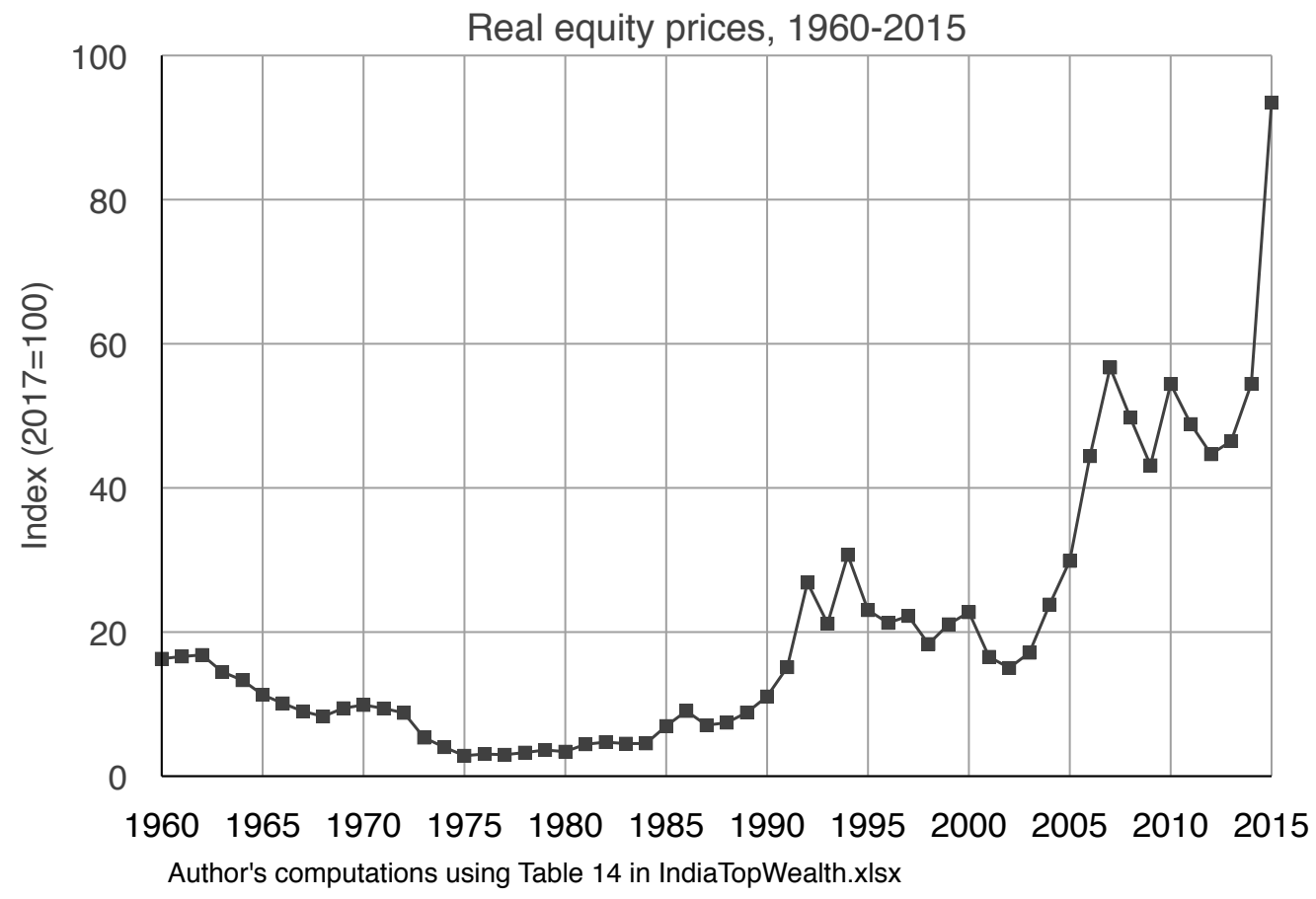

4.5.2 Political factors: nationalization, confiscation, and taxation

Finally, the political economic environment facing India's richest between 1966-1985 should realistically be understood as their experience under Indira Gandhi. As the prime minister of India from 1966 to 1977 , her policies and action evolved ${ }^{26}$ toward socialist populism. Explicit political and executive measures were

\footnotetext{
26 Note that this was in her first phase as prime minister. Gandhi's rhetoric changed in her second stint between 1982 and 1984 .
} 
designed to circumscribe and to eventually shrink the power and influence of the rich; these measures included the wealthy elements of society but also (more explicitly) members of Gandhi's own Congress party such as the erstwhile princely class.

Gandhi's rise to prime minister came at a time of within-party instability, precipitated by the death of her father (former Prime Minister Nehru). Consolidating power in parliament required aligning with leftist political parties, and winning elections meant running on pro-poor/anti-rich platforms. Almost $70 \%$ of the banking sector was nationalized under the 1970 Banking Companies Act to restrict the private sector's financial power (Khanna and Palepu, 2005) and to reorient banks toward priority lending. Subsequently, the coal sector was also nationalized between 1971 and 1973. Nationalizations fit the prevailing industrial theme of the Hindu growth period, but they were also a useful strategy to reduce the influence of large industrialists on competing political parties. Gandhi had been campaigning in elections under a social emancipation message of "garibi hatao" (end poverty). As a political strategy, promising the alleviation of poverty and demonstrating action against the rich turned out to be successful. Updates to the tax code followed in the the early 1970s, with Gandhi herself putting the idea of wealth redistribution through taxation 27 in budget speeches. Tax rates went from progressive to nearly confiscatory (Acharya, 2005); income and wealth taxes reached their peak by 1974, with top marginal income tax rates of $85 \%$ and surcharges of $15 \%$. Private corporations, many of which were in decline under the policy environment, also ceased to be useful places to retain business profits. Company taxes had been elevated to nearly $60 \%$ during this period.

In terms of the sheer volume of wealth lost due to taxation and politics, the biggest losers were the princely class. Between the heads and members of the ruling families, the erstwhile royalty were India's richest citizens (Table 2 ) even after the consolidation of their pre-independence territories into the Indian union. Their remaining assets had been protected from taxes by the Privy Purse Act, and they continued to receive incomes in the form of their state-sponsored stipends. Having been on top of the indigenous political hierarchy in the colonial period, members of the princely class began to re-enter ${ }^{28}$ political life after independence.

Around the 1960s, multiple frictions began appearing between the interests of the princely class politicians and other elites of the ruling Congress party. Richter (1971) argues that the eventual split in Congress itself put the princes on either end of the political spectrum. For example, some princely stipends were being used to finance local parties or national-level right-wing parties. Gandhi used their feudal legacy as part of her political strategy, antagonizing popular opinion against the entire (not just politically active) princely class. In 1971 Gandhi successfully abolished ${ }^{29}$ the privy purse and all princely

27 These policies had little impact on revenue and were meant to demonstrate the government's redistributive commitment to the public. See Rao et al. (2006).

28 By 1970, 25 members of parliament were either heads or were part of princely families (Roberts, 1972$).$

29 The process has a long history due to complications related to the Constitution. Multiple cases were filed by wealthy landowners in the 1950 s and 1960s to challenge redistributive acts such as land ceilings; see, for example, the well-known 
titles using the 26th amendment of the Constitution (Roberts, 1972). The result of this amendment was twofold: it transformed erstwhile royalty into ordinary citizens, subject to the same taxes on wealth and estates as other rich Indians, and it stopped the payment of state stipends that were earlier used to finance lavish lifestyles of the royals.

Table 2 India's top wealth tax payees by wealth rank and class as listed by India Today Magazine March 31 st 1978 "Taxes: the poor rich"

\begin{tabular}{|c|c|c|c|}
\hline Rank (net wealth) & Name & Year & Class \\
\hline 1 & Late Sir JM Scindia & $1961-62$ & Royal \\
\hline 2 & FP Gaekwad of Baroda & $1966-67$ & Royal \\
\hline 3 & Late Rameshwar Singh of Darbhanga & $1961-62$ & Royal \\
\hline 4 & Madan Singhji of Kutch & $1963-64$ & Royal \\
\hline 5 & VD Chowgule & $1973-74$ & Industrialist \\
\hline 6 & Maharaja Rama Varma & $1973-74$ & Royal \\
\hline 7 & Bhawani Snighji of Jaipur & $1969-70$ & Royal \\
\hline 8 & LD Chowgule & $1971-72$ & Industrialist \\
\hline 9 & Karnataka State Pension \& Gratuity Fund & $1975-76$ & Fund \\
\hline 10 & Gulab Kunwarba of Nawanagar & $1965-66$ & Royal \\
\hline 11 & Jagadamba Kumari of Nepal & $1958-59$ & Royal \\
\hline 12 & M Ramanamma & $1973-74$ & Unknown \\
\hline 13 & Trustees of the Nizam's Misc Trust & $1976-77$ & Royal \\
\hline 14 & Martand Singhji of Rewa & $1974-75$ & Royal \\
\hline 15 & Late Sawai Man Singhi of Jaipur & $1960-61$ & Royal \\
\hline 16 & KSRTCCP Fund Trust & $1975-75$ & Fund \\
\hline 17 & Mrs Vijay Raje Scindia & $1967-68$ & Royal \\
\hline 18 & Jai Singh of Jaipur & $1970-71$ & Royal \\
\hline 19 & Mishri Lal Jain of Ranchi & $1975-76$ & Industrialist \\
\hline 20 & Prithvi Raj of Jaipur & $1970-71$ & Royal \\
\hline
\end{tabular}

The abolition of the privy purse had two effects that were important vis-a-vis the evolution of top wealth shares. First, it exposed India's richest families to taxation. As ordinary citizens, their assets fell in the highest tax brackets. Remember, this was already a period of aggressive taxation on wealth. From an institutional perspective, these developments reversed the AJR-type political protections that allowed the dynastic transmission of aristocratic wealth. At the time of abolition, a majority of their assets were unproductive (multiple palaces, jewels, art), making a large fraction of their personal net worth eligible for wealth taxation. Audits on their estates were imposed retroactively to cover the years prior to 1971; given their social position, the obvious scrutiny from tax authorities was unavoidable. Amplifying the strain was the fact that few others wished to purchase such large assets due to the associated taxes. Therefore the market value of these unproductive assets plummeted further.

Golak Nath case (1967 AIR 1643). The Constitution offered protection for the right to own personal property. See the legal complications in Roberts (1972). 
Second, due to the prior stipends, most of the royals had not envisaged finding other sources of income. Without their purses, the only alternative was to consume their personal wealth at much higher rates than before. While a handful of the more entrepreneurial members among the princes were able to turn their assets into profitable investments (such as boutique hotels), most ended up depleting much of their wealth. The obsolescence of the princely clas $\$^{30}$ soon became part of popular discussion and newspaper reports. For all practical purposes, this period ended the royals' position as India's richest. So far, none of the princely families have been placed on any 32 "richest Indians" list in the twenty-first century.

\subsection{After 1985: brief remarks}

Although comparable data cease with the abolition of the estate tax, there is suggestive evidence that the trends shown in this article were reversed after 1985. First, accumulating wealth became easier. The direct tax reform of the early 1990s ended (or diluted) the confiscatory ${ }^{33}$ regime of the 1970s (Acharya, 2005). Second, the policy environment shifted starting with Gandhi's return to power in 1982. The anti-business attitudes of the political class subsided, and growth through private investment began appearing as a more realistic route toward development (Rodrik and Subramanian, 2005, Kohli, 2006). Deregulation of industrial policy followed, along with reverse nationalizations and sales of public enterprises. Real equity prices also surged ${ }^{34}$ in the 1990s (Figure 11. Survey-based estimates (admittedly missing the richest) have shown rising wealth inequality since 1991 (Anand and Thampi, 2016), driven by growing gaps between urban and rural classes. Roine and Waldenström (2015) identify the rise of top wages as one of the main factors behind the rise of wealth inequality in other countries since the 1980s. Given that Banerjee and Piketty (2005) had already identified wage growth behind the return of income concentration in the mid-1980s, trends for India may be similar.

\footnotetext{
30 To put the drama and numbers into context, according to Time Magazine's estimate, the Nizam of Hyderabad alone had wealth equivalent to $10 \%-15 \%$ of India's national income in 1937.

31 For example, the Darbhanga estate was assessed as the third wealthiest property holding (Table 2 by the tax authorities. This estate was India's largest landowner while the princely class retained its privileges. Also within the portfolio were real estate holdings in metropolitan cities and Europe. The downfall of the Darbhanga estate is seen as the classic case of feudal royalty perishing to taxation and disputes over inheritance. See "Darbhanga provides a classic study of the decline and fall of India's feudal ruling class": India Today Magazine, August 151982.

32 According to the 2017 Hurun Rich List, published by the Hurun Research Institute, there is no former princely head or relative in the richest 600 Indians.

33 According to Barro-Becker type dynastic models (Barro and Becker 1989), a permanent truncation at the top of the wealth distribution is only feasible if progressive direct taxes are sustained in the long run. Obviously, although the rate of taxation had been confiscatory in Hindu growth India, it was simply too small (relatively) a period to permanently lower wealth concentration in India.

34 In 2017, the top 200 richest individuals (all business owners) are worth almost three times the top $0.01 \%$ of 1967 . The 2017 data were obtained using the Huron Rich Lists produced by the Hurun Research Institute. Computations are available in the supplementary database.
} 


\section{Conclusion}

This article has presented new annual series that show a reduction of top Indian wealth shares between 1966 and 1985. This trend is consistent with the political and economic setting that characterized the early independence decades. In the long run, the Hindu growth years should be seen as a digression. Inequality had risen in the feudal and laissez-faire environment of the colonial period. Although my series show a reversal of wealth and income concentration, the main policies (high rates and broad taxation, nationalization, regulations) that created hostile conditions for the rich did not last beyond the Hindu growth years. Indeed, other research suggests that inequality is rising again in post-liberalized India (1991 onward).

The estimates provided in this article should be understood within the limits imposed by the data and the battery of underlying assumptions. They are by no means a final answer regarding inequality in India. Instead, these estimates are an attempt to continue a historically grounded debate on a question of deep relevance for a democratic society grappling with development and inherent frictions vis-a-vis social mobility. The biggest challenge for future research is to extend these top wealth shares further, especially given that no comparable fiscal sources exist in India anymore.

Acknowledgements I am grateful to participants at various seminars where earlier drafts of this research were presented. Special thanks to Dr Suranjali Tandon and anonymous members of the Income Tax Department for their assistance in obtaining the relevant data and for guidelines regarding tax policies. Comments from Vimal Balasubramaniam, Daniel MacDonald, Thomas Piketty and Sanjay Reddy have contributed tremendously to improving this article. Two anonymous referees provided very useful comments and suggestions which (among other aspects) also broadened the relevance of this article. All errors are solely my own. 


\section{References}

Acemoglu D, Johnson S, Robinson JA (2002) Reversal of fortune: Geography and institutions in the making of the modern world income distribution. The Quarterly Journal of Economics 117(4):12311294

Acharya S (2005) Thirty years of tax reform in india. Economic and Political Weekly pp 2061-2070

Alfani G (2017) The rich in historical perspective: evidence for preindustrial europe (ca. 1300-1800). Cliometrica 11(3):321-348

Alvaredo F, Bergeron A, Cassan G (2017) Income concentration in british india, 1885-1946. Journal of Development Economics 127:459-469

Anand I, Thampi A (2016) Recent trends in wealth inequality in india. Economic and Political Weekly 51(50):59-67

Atkinson AB (2008) Concentration among the rich. In: Davies J (ed) Personal Wealth from a Global Perspective, Oxford University Press, pp 64-89

Atkinson AB, Harrison AJ (1978) Distribution of personal wealth in Britain. Cambridge Univ Pr

Banerjee A, Iyer L (2005) History, institutions, and economic performance: The legacy of colonial land tenure systems in india. American economic review 95(4):1190-1213

Banerjee A, Piketty T (2005) Top indian incomes, 1922-2000. The World Bank Economic Review 19(1):120

Barro RJ, Becker GS (1989) Fertility choice in a model of economic growth. Econometrica: journal of the Econometric Society pp 481-501

Chancel L, Piketty T, Saez E, Zucman G (2018) World Inequality Report 2018. Cambridge: Belknap Press

Das Gupta C, Gupta M (2017) The hindu undivided family in independent india's corporate governance and tax regime. South Asia Multidisciplinary Academic Journal (15)

Davies JB, Shorrocks AF (2000) The distribution of wealth. Handbook of income distribution 1:605-675

Deininger K, Goyal A, Nagarajan H (2013) Women's inheritance rights and intergenerational transmission of resources in india. Journal of Human Resources 48(1):114-141

Joshi J, Venkataraman L (1980) Mortality of indian assured lives. Economic and Political Weekly pp M101-M106

Khan AA (1986) Critical study of the estate duty and gift taxation in india. Master's thesis, Aligarh Muslim University

Khanna T, Palepu K (2005) The evolution of concentrated ownership in india: broad patterns and a history of the indian software industry. In: A history of corporate governance around the world: Family business groups to professional managers, University of Chicago press, pp 283-324

Kohli A (2006) Politics of economic growth in india, 1980-2005: Part i: The 1980s. Economic and Political Weekly pp 1251-1259

Kopczuk W, Saez E (2004) Top wealth shares in the united states, 1916-2000: Evidence from estate tax returns. National Tax Journal 57(2):445-87 
Maddison A (1971) Class structure and economic growth: India and Pakistan since the Moghuls. Taylor \& Francis

Mallet B (1908) A method of estimating capital wealth from the estate duty statistics. Journal of the Royal Statistical Society 71(1):65-101

Parekh B (1991) Nehru and the national philosophy of india. Economic and Political Weekly pp 35-48

Piketty T (2003) Income inequality in france, 1901-1998. Journal of political economy 111(5):1004-1042

Piketty T (2011) On the long-run evolution of inheritance: France 1820-2050. The quarterly journal of economics 126(3):1071-1131

Piketty T (2014) Capital in the Twenty-First Century. Harvard University Press

Piketty T, Postel-Vinay G, Rosenthal JL (2006) Wealth concentration in a developing economy: Paris and france, 1807-1994. American economic review 96(1):236-256

Ramusack BN (2004) The Indian princes and their states. Cambridge University Press

Rao MG, Rao RK, et al. (2006) Trends and issues in tax policy and reform in india. In: India Policy Forum, National Council of Applied Economic Research, vol 2, pp 55-122

Rawal V (2008) Ownership holdings of land in rural india: Putting the record straight. Economic and Political Weekly pp 43-47

Richter WL (1971) Princes in indian politics. Economic and Political Weekly pp 535-542

Roberts NA (1972) The supreme court in a developing society: Progressive or reactionary force? a study of the privy purse case in india. The American Journal of Comparative Law 20(1):79-110

Rodrik D, Subramanian A (2005) From" hindu growth" to productivity surge: The mystery of the indian growth transition. IMF Economic Review 52(2):193

Roine J, Waldenström D (2015) Long-run trends in the distribution of income and wealth. In: Handbook of income distribution, vol 2, Elsevier, pp 469-592

Roy T (2002) Economic history and modern india: redefining the link. Journal of Economic Perspectives 16(3):109-130

Roy T (2016) The british empire and the economic development of india (1858-1947). Revista de Historia Economica-Journal of Iberian and Latin American Economic History 34(2):209-236

Roy T (2017) Transfer of economic power in corporate calcutta, 1950-1970. Business History Review 91(1):3-29

Roy T (2018) A business history of India: enterprise and the emergence of capitalism from 1700. Cambridge University Press

Roy T, Swamy AV (2016) Law and the economy in colonial India. University of Chicago Press

Saez E, Zucman G (2016) Wealth inequality in the united states since 1913: Evidence from capitalized income tax data. The Quarterly Journal of Economics 131(2):519-578

Salvatore C, Tomasso G, Mukherjee A (2000) Government employment and pay in global perspective. Washington: World Bank

Scheve K, Stasavage D (2016) Taxing the rich: A history of fiscal fairness in the United States and Europe. Princeton University Press 
Sivasubramonian S (2000) The national income of India in the twentieth century. Oxford University Press, USA

Zacharias A, Vakulabharanam V (2011) Caste stratification and wealth inequality in india. World Development 39(10):1820-1833 


\section{Appendices}

\section{A Replication material}

Supplementary material such as replication codes, raw data, summary tables can be accessed by visiting this link. All tables and figures in the main text utilize the database file IndiaTopWealth.xlsx. The entire collection of spreadsheets can be recreated using the raw files and accompanying Stata programs (in .do format). All instructions to replicate the summary tables are given in the file DataReadMe.txt - some information in the appendices that follow overlaps with information provided in the instructions file. The main programs/files used are listed below:

- Main comprehensive summary database: IndiaTopWealth.xlsx

- Raw files: Raw_Data

- Stata programs: Stata_Codes

- Program to recreate all figures: 2000_graphs.do

- Program to recreate IndiaTopWealth.xslx: 1000_excel_estates

The full replication archive (raw files, Stata programs, figures and spreadsheets) are contained in the file IndiaTopWealthReplicate.zip

\section{A.1 Replication Files}

- All macro series were downloaded from public databases. Stata programs are prefixed with $\mathbf{z}$ eg: z_1_exchangerate

- Estate tax computations are carried out in Stata programs numbered (prefixed) 1-14

- Estate multiplier computations are carried out in Stata programs numbered (prefixed) 15-20

- Estate taxes and decomposition of inheritance flows are carried out in programs numbered (prefixed) $21-22$

- Wealth tax computations and comparison with estate taxes - programs numbered (prefixed) 23-26

- The remaining files are miscellaneous computations (given in .do file)

\section{A.2 Raw files}

The folder Raw_Data has all raw digitized spreadsheets/stata datasets. These include:

- estate_returns.xlsx: All raw estate tabulations

- wealth_returns.xlsx: All raw wealth tax tabulations

- richest_20xx.dta: Rich lists downloaded from Hurun Research Institute for 2015, 2016 and 2017

Also given are pdf reports of high net worth individuals (between 2015-17), India Today article Taxes: the poor rich and other reports using in the main article. 


\section{B Further notes on data and methods}

\section{B.1 Workings of the estate and wealth tax}

The Estate Duty Act was implemented in 1953 and charged on the net principal value of the estate. The decedent's property passing on death included movable property (in India or abroad) and immovable property situated in India. One residential property valued up to Rs 100,000 was also exempt from estate duty. By definition, the tax applied to individuals (decedents) rather than households or joint tax units. The strength of this tax code was best in assets where transfer of ownership required paperwork/validation - real estate, equities, contents of bank accounts, life insurance settlements etc. Contents of the house (where possession grants ownership) were easier to evade. For the inheritors, exemption certificates issued after evaluation were mandatory to obtain wealth tax and stamp duty exemptions. This also gives the estate tax a significant advantage as a data source relative to other taxes. Due to the legal burden of proof for inheritors, including disputes, it was beneficial to file estate duty. For example, even where the decedent was formerly an employed person on low wages but with rights to provident funds (a social security type scheme for public employees), beneficiaries were required to produce estate duty exemption certificates. Any gift made in anticipation of death would be included in the principal value of the estate; this included all gifts made in the two years before the decedent passed away. From the tabulations, it appears that estate duty filers comprised the richest $0.14-0.32 \%$ decedents between the years 1966-85.

In case the individual was not the sole owner of an asset, his/her equity in the community property was calculated according to Hindu Law. The family that jointly owned this property was defined as a Hindu Undivided Family (HUF) and distribution of equity was based on lineage rules based on Hindu Law (Das Gupta and Gupta, 2017). This system made the holding structure of family property property analogous to a corporation except the shareholders were family members. Males held precedence over females (Deininger et al. , 2013) and age/generation was a secondary factor - older males held higher shares than younger males in the same generation. Over $90 \%$ estates were filed under sole individuals and the remaining under HUF.

I also utilize tabulations from the 1957 Wealth Tax Act. This progressive wealth tax was charged on unproductive assets i.e assets which did not generate income. As in other countries, there is less reliability in using wealth taxes to systematically compute wealth shares. I employ them purely to compare the population and upper tails of rich wealth-holders against results from estate computations. Fiscal definitions changed frequently depending on the budget - in some periods, luxury consumer goods were also charged wealth tax. Exemption limits were throughout much higher (at Rs 100,000) than for estate taxation and so applied to a very small proportion of the population. The liable base was the tax unit (similar to income taxes), including on occasion companies. Overall this tax was very strongly afflicted by evasion since property value and size estimates were only confirmed through random audits. Top marginal rates varied between 4-9\% (Acharya, 2005). 
Fig. B.1 Upper tails of the distribution of wealth estimated using estate and wealth tax returns

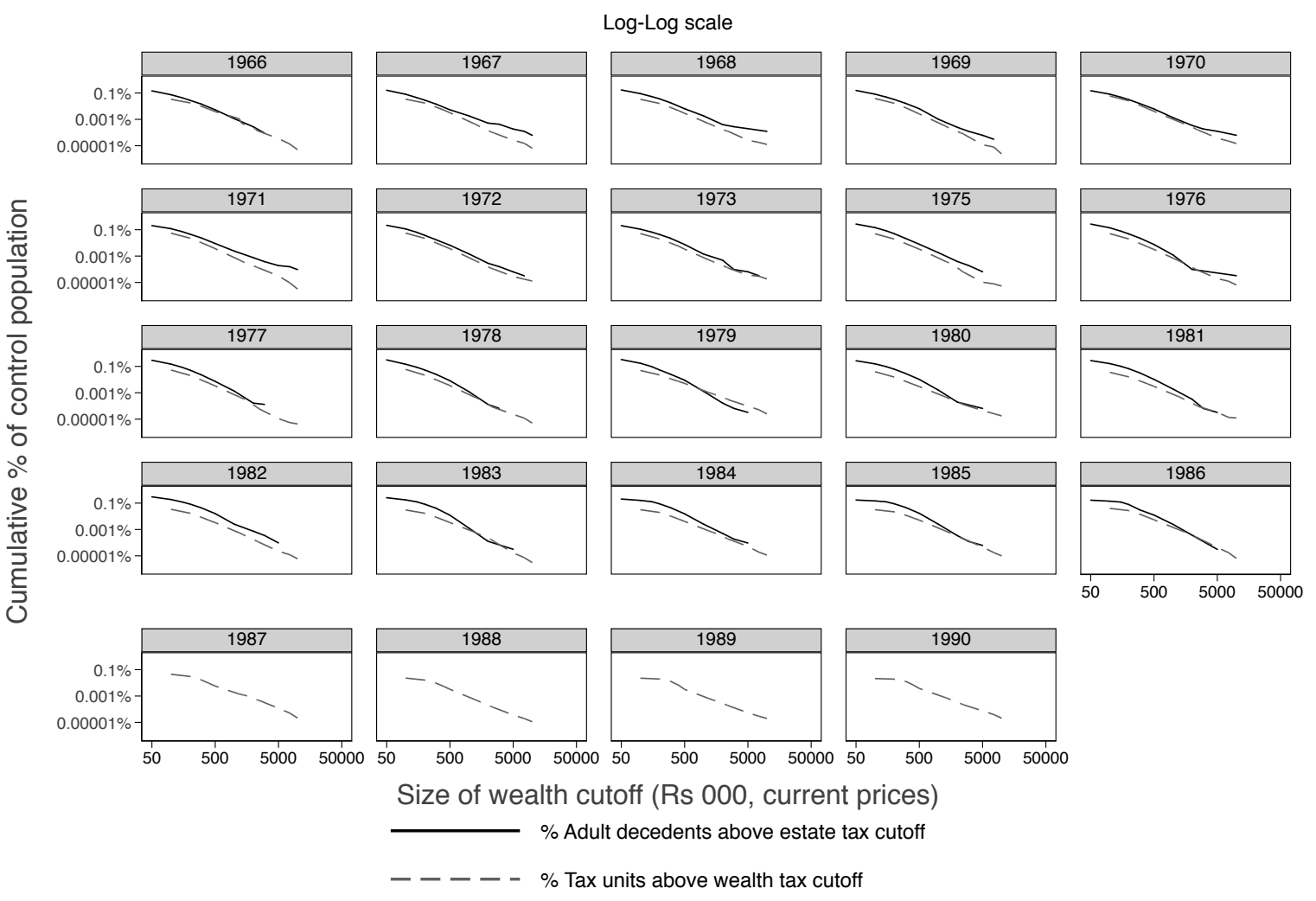

Author's computations using Table 12 in IndiaTopWealth.xlsx

\section{B.2 Limitations of the uniform multiplier}

The implications of using a uniform multiplier applied to the entire estate filing population (adult decedents) are important and I address them here briefly.

First, the rich may face lower mortality risk $(m)$. The estate multiplier will then be biased downward because $m_{\text {rich }}<m_{\text {population }} \rightarrow\left(1 / m_{\text {rich }}\right)>\left(1 / m_{\text {population }}\right)$. One solution, such as for instance in Kopczuk and Saez (2004), is to use a suitable mortality rate for the rich. For example, estimates of mortality risk are developed by actuaries for life insurance contracts. These life tables however are only useful if estates are at the unit level so that these mortality rates can then be matched to a decedent by age (and preferably also by gender). It is however unclear if this would make a difference if only average mortality rates are applied indiscriminately to each estate. For the Indian population, comparisons of assured adult mortality rates are available for 1970-73 using a Life Insurance Corporation (LIC) estimate by Joshi and Venkataraman (1980). Compared to the population level mortality rate, I found almost no difference in the average derived from these rates. At the same time, the former measure of mortality risk is available annually.

From the outset it should be stated that estate multipliers computed without age or gender information can produce biased estimates. But even perfectly applied estate multipliers with micro-data on estate, age 
and gender must assume similarity of behavior within age/gender cells. For example, if one finds an estate belongs to a female aged 72 whose mortality risk was (say) $10 \%$ then the underlying assumption is that 10 females aged 72 take deterministic steps towards lifetime wealth planning. They marry, save, consume and split wealth the same way. So assumptions always apply and results are always approximations. Certainly my approach has limitations because it is equivalent to assuming that the wealth distribution for the living is no different from the wealth distribution of decedents. A comparison of upper tails is possible using returns from both the wealth tax (living) and estate duty (decedents). This is shown in Figure B.1. The bulk of the upper tail is similar for both the respective populations. Atkinson (2008) argues that the problem is acute only if the uniform multiplier is applied to the full population and then used to estimate the entire wealth distribution. Atkinson's logic is that time would increase the gap between the poor and the rich and this disparity would be reflected at death. Thus a complete distribution approximated using estates (top 10\%, bottom $40 \%$ etc) would overestimate wealth inequality. But if the uniform multiplier is being used only to reconstruct the rich, then these biases would have a much more limited impact.

\section{B.3 Limitations of the benchmark dataset}

This dataset should be understood with three main limitations.

1. Discrepancies in estate tax returns: The main limitation of using tax returns is evasion. On estate duty, this was less common - note that despite falling mortality, there is a substantial increase in the number of estates recorded under the tax code till at least 1980 (when exemption limits were raised). And, the average estate increased in nominal value; which remember was being decided by tax controllers rather than self-reporting. In the wealthiest Indian city (Bombay), audits between 1978-82 found only 14 cases where penalties for evasion were charged (Khan, 1986).

Another possibility is reduced estate size through gifts in anticipation of death. Again there are three important checks in this case. First, all gifts made two years prior to death were included in the principal value of the estate. Second, all other sizable gifts would be liable under the 1958 Gift Tax Act. The tax rate on gifts was charged on the full (rather than marginal) value about the limit. Relative to the estate tax exemption (Rs 50,000), the gift tax was actually higher. Third, estates did not lend themselves to divisibility easily - it requires the break up and sale of existing assets like real estate to recover much more divisible assets (like cash). The simple fact is that an estate is a person's wealth-at-death. Transfers quite simply re-allocate these large wealth holdings between persons. As long as these gifts are made to persons of a different age, they are effectively already captured in when the estate is blown up into the wealth of the living. Finally the 1966-86 series is best understood as representing more comprehensive trends until 1982. Starting this year, 4-5 states removed estate taxes on agricultural property resulting in lower average wealth levels (in real terms). The remaining years (1983-86) have been included to improve temporal data coverage.

2. Limitations of the estate multiplier: Even perfectly computed estate multipliers have downsides related to randomness of death and differential mortality in the population. These are discussed in the 
appendix of Kopczuk and Saez (2004) and section 2.3 of Atkinson (2008). By extension, they apply in this present article as well.

3. Downward bias due to gender: Laws of inheritance in India have been biased against women and Hindu Law created unequal bequests depending on the inheritor's gender (Deininger et al., 2013). Realistically, it is possible that wealth inequality ${ }^{35}$ between men and women is large. Individuals are not necessarily the best representation of the population since married women would not get the same inheritance benefits as (say) their brothers or male children. Equal-split between husband and wife is thus not applicable in the Indian case. Wealth inequality is likely to be biased upward once women's asset ownership gap is taken into account.

35 A handful of women are listed in named lists (Forbes, Hurun Research Institute) of the richest Indians in the twenty first century. 